\title{
Impact of rising body weight and cereal grain food processing on human magnesium nutrition
}

\author{
Andrea Rosanoff • Diriba B Kumssa
}

Received: 14 October 2019 / Accepted: 3 March 2020/Published online: 14 March 2020

(C) The Author(s) 2020

\begin{abstract}
Aim The World Health Organisation (WHO) magnesium $(\mathrm{Mg})$ estimated average requirement (EAR) is not adjusted for rise in human body weight (BW) and neglects body $\mathrm{Mg}$ stores depletion. Cereal grain food processing results in $\mathrm{Mg}$ loss and reduces dietary $\mathrm{Mg}$ intake which mainly originates from cereals. Here we reassess human dietary $\mathrm{Mg}$ deficiency risk considering actual human BWs and modern levels of cereal grain food processing.

Methods Human Mg requirement was adjusted for rising BW plus low and high estimates to prevent body $\mathrm{Mg}$ store depletion. Magnesium supply was recalculated for cereal grain (maize, millet, rice, oats, sorghum, and wheat) food processing of none, $25 \%, 50 \%, 75 \%$ and 100\%. Resulting Mg deficiency risks in 1992 and
\end{abstract}

Andrea Rosanoff and Diriba B Kumssa contributed equally to this work.

Responsible Editor: Ismail Cakmak.

Electronic supplementary material The online version of this article (https://doi.org/10.1007/s11104-020-04483-7) contains supplementary material, which is available to authorized users.

A. Rosanoff

Center for Magnesium Education and Research, LLC, Pahoa, HI 96778, USA

\section{B. Kumssa $(\triangle)$}

School of Biosciences, University of Nottingham, Sutton

Bonington Campus, Leicestershire, UK

e-mail: diriba.kumssa1@ nottingham.ac.uk
2011 were calculated at national, regional, continental and global scales using the EAR cut-point method. Results Globally, human $\mathrm{Mg}$ requirement increased by 4-118\% under the three $\mathrm{Mg}$ requirement scenarios compared to the WHO EARs set in 1998. However, dietary $\mathrm{Mg}$ supply declined with increased cereal grain food processing. At $100 \%$ cereal grain processing, dietary Mg supply was reduced by 56\% in 1992 and $51 \%$ in 2011. Global human $\mathrm{Mg}$ deficiency risk reached $62 \%$ in 2011 with $100 \%$ cereal grain processing and largest EAR set to prevent depletion of body $\mathrm{Mg}$ stores and corrected for BW rises.

Conclusion Global dietary Mg Supply adequately meets human $\mathrm{Mg}$ requirement given the global obesity epidemic. But, $\mathrm{Mg}$ intakes preventing body $\mathrm{Mg}$ store depletion plus high $\mathrm{Mg}$ losses due to cereal grain food processing start to show noteworthy risks of potential $\mathrm{Mg}$ deficit in populations consuming diets with $>50 \%$ cereal grain food processing. These findings have ramifications for the global spread of the major chronic, non-communicable diseases associated with nutritional $\mathrm{Mg}$ deficiencies such as cardiovascular diseases and type 2 diabetes.

Keywords Cardiovascular disease $\cdot$ Chronic latent mg deficit - Diabetes $\cdot \mathrm{Mg}$ deficiency risk - Obesity Overweight
Abbreviations
BMI Body Mass Index
BW Body Weight
CLMD Chronic Latent Magnesium Deficit 


$\begin{array}{ll}\text { EAR } & \text { Estimated Average Requirement } \\ \text { FAO } & \begin{array}{l}\text { Food and Agriculture Organisation of the } \\ \text { United Nations }\end{array} \\ \text { FBS } & \text { Food Balance Sheet } \\ \text { NCD- } & \begin{array}{l}\text { Non-communicable Disease risk factor } \\ \text { RisC }\end{array} \\ \text { Collaboration } \\ \text { RNI } & \text { Reference Nutrient Intake } \\ \text { USDA- } & \text { United States Department of Agriculture } \\ \text { NDL } & \text { Nutrient Data Laboratory } \\ \text { WHO } & \text { World Health Organisation } \\ \text { WtdEAR } & \text { Weighted Estimated Average Requirement }\end{array}$

\section{Introduction}

Magnesium $(\mathrm{Mg})$ is an essential nutrient for plants as well as animals. In humans, a low dietary $\mathrm{Mg}$ intake is associated with cardiovascular disease and its risk factors including hypertension as well as metabolic syndrome and type 2 diabetes among other chronic diseases (Ma et al. 1995; Volpe 2012; Zhang et al. 2012; Del Gobbo et al. 2013; Kass and Sullivan 2016; Zhang et al. 2016; Verma and Garg 2017; Rosique-Esteban et al. 2018). Plant source foods are the source of most human $\mathrm{Mg}$ intake, especially cereal grains, green vegetables, nuts and pulses (Nielsen 2015), with grains supplying the vast majority of dietary $\mathrm{Mg}$ to humans (EFSA Panel on Dietetic Products Nutrition and Allergies 2015; Kumssa et al. 2015).

In 2015, Kumssa et al. (2015) published an assessmentofglobalhumandietary Mgsupply, findingitample compared with human Mgrequirementas defined by the World Health Organisation (WHO) and Food and Agriculture Organisation of the United Nations (FAO) Estimated Average Requirement (EAR) for Mg (WHO and FAO 2004). When first published in 1998, these EARs were set to estimate the daily $\mathrm{Mg}$ intake level that can prevent $\mathrm{Mg}$ deficit in 50\% of healthy individuals of a given gender/age group.

These EARs are set to a standard reference body weight for each gender/age group, but recent analysis of human $\mathrm{Mg}$ balance study data (Nielsen 2019) has shown that $\mathrm{Mg}$ requirement increases with body weight. Thus, the existing WHO and FAO Mg EARs, set for standard reference body weights, are low considering the rise in obesity and overweight status in both children and adults that has been globally measured during the past 35 years (Finucane et al. 2011; Bixby et al. 2019; FAO 2019).

In addition, these EARs were not designed to prevent the depletion of human $\mathrm{Mg}$ body stores. Rather, they are based on populations' usual $\mathrm{Mg}$ intake and human $\mathrm{Mg}$ balance study data, i.e. measures of total $\mathrm{Mg}$ intake minus excretion. Since Kumssa et al. (2015) publication, research has found that homeostasis of $\mathrm{Mg}$ in human physiology not only includes control of absorption in the gastrointestinal tract and excretion via kidney but also translocation of $\mathrm{Mg}$ from bone and other storage areas to maintain blood levels during times of low $\mathrm{Mg}$ intakes, with replacement of those storage sites when $\mathrm{Mg}$ intakes again become high (de Baaij et al. 2015; Costello and Nielsen 2017). Thus, chronically suboptimal $\mathrm{Mg}$ intakes can result in a growing depletion of body $\mathrm{Mg}$ stores termed Chronic Latent Magnesium Deficit (CLMD) (Elin 2010; Rosanoff et al. 2012; Blaine et al. 2015) which can manifest in spite of measures of normal serum $\mathrm{Mg}$ and neutral $\mathrm{Mg}$ balance.

Furthermore, food processing losses of $\mathrm{Mg}$ can be great (Seeling and Rosanoff 2003), especially in staple cereal grains which are the main source of dietary $\mathrm{Mg}$ in human nutrition (EFSA Panel on Dietetic Products Nutrition and Allergies 2015; Kumssa et al. 2015). As the modern processed food diet expands globally, these $\mathrm{Mg}$ processing losses can lower human $\mathrm{Mg}$ intakes, often impacting health especially with regard to the chronic noncommunicable diseases such as heart disease and diabetes and their risk factors (Abu-Saad et al. 2009; Rosanoff 2013; Barbagallo and Dominguez 2015; de Baaij et al. 2015; Grober et al. 2015; Fang et al. 2016; Zhang et al. 2016; Razzaque 2018; Azab et al. 2019), diseases which are rising globally (Lozano et al. 2012).

This study attempts to more realistically assess current human $\mathrm{Mg}$ requirement at a global level by correcting WHO EAR Mg requirements (WHO and FAO 2004) for actual body weights in 1992 and 2011 (Scenario 1) and adjusting these with estimates of $\mathrm{Mg}$ intakes required to prevent depletion of body $\mathrm{Mg}$ stores (Scenarios 2 and 3). These realistic estimates of $\mathrm{Mg}$ requirements were then compared with dietary $\mathrm{Mg}$ supply at various levels of $\mathrm{Mg}$ loss due to cereal grain food processing to assess the risk of human $\mathrm{Mg}$ 
deficiency at various geographical scales in 1992 and 2011.

\section{Materials and methods}

Human dietary Mg requirement and supply for 1992 and 2011 were quantified, and dietary $\mathrm{Mg}$ deficiency risks were then reassessed at three scenarios of human Mg EAR (Table 1) and five scenarios of cereal grain food processing (Table 2). Human Mg EARs for each age/gender group were corrected for body weight (BW) using calculated mean global human body weights for 1992 and 2011 (Scenario 1) plus estimates to ensure prevention of body $\mathrm{Mg}$ store depletion based on published human $\mathrm{Mg}$ balance data (Scenarios 2 and 3). Food crops considered for cereal grain food processing scenarios were maize, millet, rice, oats, sorghum, and wheat.

Human magnesium requirement

Human population $\mathrm{Mg}$ requirement can be represented either by the Reference Nutrient Intake (RNI) or the Estimated Average Requirement (EAR) as reference values. The RNI is a daily $\mathrm{Mg}$ intake which meets the requirements of almost all healthy individuals in a population. The EAR is a daily $\mathrm{Mg}$ intake level that meets the $\mathrm{Mg}$ requirements of $50 \%$ of the healthy individuals in a population. In this study, the EAR was used as it is appropriate to estimate the proportion of individuals in a population with $\mathrm{Mg}$ intakes below the median $\mathrm{Mg}$ requirement (i.e., EAR) using the EAR cut-point method (Institute of Medicine 2000). The proportion of the population with $\mathrm{Mg}$ intake below the EAR are

Table 1 Human Mg Estimated Average Requirement (EAR) scenarios

\begin{tabular}{ll}
\hline EAR scenario $^{\S}$ & Description \\
\hline i & Body weight (BW) corrected \\
ii & BW corrected plus Low estimate body \\
& Mg store maintenance \\
iii & BW corrected plus High estimate body \\
& Mg store maintenance
\end{tabular}

${ }_{\S \text { Based on WHO/FAO Reference Nutrient Intake (RNI) converted }}$ to EAR using a coefficient of variation of $10 \%$, see Online Resource Supplementary Table 1 and 2
Table 2 Cereal (maize, millet, oats, rice, sorghum, and wheat) grain food processing scenarios. Grain $\mathrm{Mg}$ concentration data were downloaded from the United States Department of Agriculture Nutrient Data Laboratory (https://fdc.nal.usda.gov/)

\begin{tabular}{lc}
\hline Cereal grain food processing scenario & Description \\
\hline a & $\begin{array}{c}\text { No processing } \\
\text { (whole grain) }\end{array}$ \\
b & $25 \%$ processing \\
c & $50 \%$ processing \\
d & $75 \%$ processing \\
e & $100 \%$ processing \\
& (refined grain) \\
\hline
\end{tabular}

at risk of $\mathrm{Mg}$ deficiency. Three corrected estimates of human Mg EARs ( $\mathrm{mg}$ capita ${ }^{-1} \mathrm{~d}^{-1}$ ) for the 56 gender and age group (see Online Resource Supplementary Table 1) were used to calculate the global, continental, regional and national $\mathrm{Mg}$ Weighted Estimated Average Requirements (WtdEARs) in 1992 and 2011. The EARs for the three scenarios (Table 1) were derived from WHO/ FAO RNIs (WHO and FAO 2004) for each gender/ age group corrected for actual mean global BWs for 1992 and 2011 (scenario 1) then further corrected for low (scenario 2) and high (scenario 3 ) estimates of dietary $\mathrm{Mg}$ required to prevent depletion of body stores (see Online Resource Supplementary Table 2). The EAR for each gender/age group was calculated from the corresponding RNI using the WHO/FAO assumed coefficient of variation of $10 \%$, i.e. $\mathrm{EAR}=\mathrm{RNI} / 1.2$. Standard body reference weights $(\mathrm{kg})$ and RNI factors ( $\mathrm{mg} \mathrm{Mg} \mathrm{kg}^{-1}$ ) for each gender/age group from the FAO WHO Expert Consultation on Human Vitamin and Mineral Requirements (WHO and FAO 2004) are reproduced in the Online Resource Supplementary Table 2.

Derivation of reference nutrient intake (RNI) estimates for three estimated average requirement (EAR) scenarios

RNIs for each gender/age group were calculated using Eq. 1 using the RNI factors given in the Online Resource Supplementary Table 2 and actual mean BWs.

Equation 1 Correcting the Reference Nutrient Intake (RNI) for rise in body weight (BW) and the depletion of body $\mathrm{Mg}$ stores 
$R N I=$ Mean $B W \times R N I$ factor

Where, Mean $\boldsymbol{B W}$ is the mean global body weight of a given gender/age group in 1992 or 2011, and $\boldsymbol{R} \boldsymbol{N I}$ factor is the factor $\left(\mathrm{mg} \mathrm{Mg} \mathrm{kg} \mathrm{d}^{-1}\right.$ per person required to either provide simple $\mathrm{Mg}$ balance (as per the $\mathrm{WHO} /$ FAO RNI, i.e. Scenario 1) or to provide enough $\mathrm{Mg}$ to prevent the depletion of body Mg stores (as per Scenarios 2 and 3).

RNI factors (mg Mg kg${ }^{-1} \mathrm{~d}^{-1}$ ) for Scenario 1 were calculated for all gender/age groups using original assumed BWs and RNIs of the WHO/FAO (See Online Resource Supplementary Table 2), e.g. $4.0 \mathrm{mg} \mathrm{Mg} \mathrm{kg}^{-1}$ $\mathrm{d}^{-1}$ for adults aged 19-65 yrs. Estimated adult RNI factors 6.5 and $8.0 \mathrm{mg} \mathrm{Mg} \mathrm{kg}^{-1} \mathrm{~d}^{-1}$, derived from adult human Mg balance studies (Seeling 1964; Hunt and Johnson 2006), were used for the "low" (Scenario 2) and "high" (Scenario 3) estimates, respectively, of the $\mathrm{Mg}$ factor needed for healthy adults to prevent depletion of body $\mathrm{Mg}$ stores. Scenario 2 and 3 factors for nonadult gender/age groups were calculated in proportion, multiplying Scenario 1 factors for each gender/age group by the fractions $6.5 / 4$ for scenario 2 and $8 / 4$ for scenario 3 (see Online Resource Supplementary Table 2).

WHO RNI factor for adults aged $>65$ yrs. is 3.5 rather than $4.0 \mathrm{mg} \mathrm{Mg} \mathrm{kg}{ }^{-1} \mathrm{~d}^{-1}$. This smaller factor was used to calculate Scenario 1 but not Scenarios 2 and 3 for these older adults since recent analysis of $\mathrm{Mg}$ balance vs human age in subjects aged 19-81 yrs. showed no decrease in balance above 65 yrs., (Hunt and Johnson 2006). That means the same RNI factors were used for all adults in Scenarios 2 and 3. WHO RNI adds $50 \mathrm{mg} \mathrm{Mg} \mathrm{d}^{-1}$ for lactation. We added $50 \mathrm{mg} \mathrm{Mg}$ $\mathrm{d}^{-1}$ for lactation for Scenarios 1 and 2 and $100 \mathrm{mg} \mathrm{Mg}$ $\mathrm{d}^{-1}$ for lactation for Scenario 3 .

Calculation of actual mean global human body weights in 1992 and 2011

Global BWs for child (5-19 yrs) and adult (>19 yrs) gender/age groups were calculated with body mass index (BMI) and height data using Eq. 2:

Equation 2 Actual body weight (BW) calculation

$B W=B M I \times(\text { height })^{2}$
Where, $\boldsymbol{B} \boldsymbol{W}$ is the mean body weight ( $\mathrm{kg}), \boldsymbol{B} \boldsymbol{M I}$ is the mean body mass index $\left(\mathrm{kg} \mathrm{m}^{-2}\right)$, and height $(\mathrm{m})$ is the mean height of an age group.

Children (5-19 yrs) Non-communicable Disease risk factor Collaboration (NCD-RisC) provided data of mean body mass index (BMI) by age (5-19 years) and gender for years 1992 and 2011 for 200 countries (NCD-RisC 2016). These were used to calculate mean global BMI for each age/gender group, ages 5-19 yrs. These arithmetic means for global BMI and WHO report of global mean heights by gender and age for children aged 5-19 yrs. (WHO 2019a) were used to calculate actual mean global BWs for children (519 yrs) using Eq. 2. The WHO global mean heights for children were collected between 1997 and 2003; we assumed no height change between 1992 and 2011 for this group of calculations.

Adults (>19 yrs) NCD-RisC (NCD-RisC 2016) provided age-standardized global mean BMI for both men and women (age > 19 yrs) for years 1992 and 2011. NCD$\mathrm{RisC}$ also provided average height at age 18 for birth years 1896-1996 for 200 countries. We calculated actual mean global body weight for adults for 1992 and 2011 using:

a) global BMI for men and women for years 1992 and 2011 using data from NCD-RisC,

b) average mean global height data for men and women at the age of 18 yrs for 200 countries for birth years 1974 and $1993(1974+18=1992 ; 1993+$ $18=2011$ ), using the formula in Eq. 2.

Infants and young children (0-5 yrs) Using mean BW for children ages $0-5$ yrs from data provided by WHO child growth standards, data accumulated between 1997 and 2003 for girls (WHO 2019c) and boys (WHO 2019b) resulted in $\mathrm{Mg}$ requirements that were 7 to $26 \%$ below the RNI for $0-4$ yrs which is based on adequate and usual intakes rather than based upon BW considerations. Thus, we used the $60 \mathrm{mg} \mathrm{Mg} \mathrm{d}^{-1}$ for the average RNI for children aged 0-4 yrs for both boys and girls. We assumed no increase in BW between 1992 and 2011 due to the obesity epidemic for infants and young children. 
Pregnancy and lactation WHO RNI does not add extra $\mathrm{Mg}$ requirements for pregnancy. In this analysis we assumed increases of BW during pregnancy as follows: trimester $1(+6 \mathrm{~kg})$, trimester 2 $(+12 \mathrm{~kg})$, trimester $3(+18 \mathrm{~kg})$, and added an assumed average of $12 \mathrm{~kg}$ to adult women BWs to calculate RNIs for all pregnancy groups. For lactating women groups, we used the same mean BW for adult women in the corresponding age group and added $50 \mathrm{mg} \mathrm{Mg} \mathrm{d}^{-1}$ for lactation for EAR Scenarios 1 and 2 and $100 \mathrm{mg} \mathrm{Mg} \mathrm{d}^{-1}$ for lactation for Scenario 3.

\section{Dietary magnesium supply}

The daily per capita food supply, food composition and national level demographic data were obtained from Food and Agriculture Organization of the United Nations (FAO), United States Department of Agriculture National Nutrient Data Laboratory (USDANDL) and the United Nations Department of Economic and Social Affairs Population Division, respectively, as described in (Kumssa et al. 2015). Determination of the national, regional, continental and global level estimates of human dietary $\mathrm{Mg}$ supply was carried out using the method of Kumssa et al. (2015).

The FAO food balance sheet (FBS) provides per capita supply of rice in either paddy or milled equivalent. We assumed that the most commonly used form of whole rice for human consumption excludes the hull which constitutes about $20 \%$, but may include the bran 8-12\% (IRRI 2019). Hence, we used the milled equivalent rice data from the FAO FBS but accounted for the $8-12 \%$ bran lost during milling. We assumed, on average, $10 \%$ of the milled rice has been lost. Hence, we divided the per capita milled rice supply data by 0.9 to calculate a new per capita whole rice supply data prior to calculating the amount of dietary $\mathrm{Mg}$ from rice at various processing scenarios.

Food supply data for the Democratic Republic of the Congo (COD) was not available in the FAO FBS database. Due to this, the values displayed on the dietary $\mathrm{Mg}$ supply and deficiency risk maps for COD were the median values of the countries bordering it (i.e., AGO, CAF, COG, RWA, UGA, ZMB, SSD). Maps were produced using ESRI ArcGIS 10.6 .
Cereal grain food processing

Firstly, cereal grain $\mathrm{Mg}$ concentration data for whole (no processing) and refined (100\% processed) for maize, millet, oats, rice, sorghum and wheat were downloaded from the USDA-NDL. Whenever there were more than one $\mathrm{Mg}$ concentration value in either the whole or refined category for a given cereal grain, an average $\mathrm{Mg}$ concentration was calculated (see Online Resource Supplementary Table 3). Average Mg concentration values for whole cereal grains were used for cereal grain food processing scenario 1, i.e. no processing, and average $\mathrm{Mg}$ values for refined cereal grains were used for cereal grain food processing scenario 5, i.e. $100 \%$ processed (refined). Secondly, the daily per capita food supply data of the six cereal grains in 1992 and 2011 reference years were queried from Kumssa et al. (2015) database and split into $25 \%, 50 \%$ and $75 \%$. Thirdly, the estimates of $\mathrm{Mg}$ supply at the five cereal grain food processing scenarios was calculated using the respective cereal grain food supply data and the two $\mathrm{Mg}$ concentration values for each cereal grain. For example, to estimate the amount of dietary $\mathrm{Mg}$ at $50 \%$ cereal grain food processing scenario, we multiplied $50 \%$ of the cereal grain food supply by the $\mathrm{Mg}$ concentration with no cereal grain food processing (whole) value and the remaining $50 \%$ of the cereal grain food supply by the $100 \%$ cereal grain food processing (refined) $\mathrm{Mg}$ concentration value.

Dietary magnesium deficiency risk

National, regional, continental and global scale human dietary $\mathrm{Mg}$ deficiency risk at the three scenarios of rise in Mg EAR due to increase in human body weight and correction for body $\mathrm{Mg}$ store depletion, and reduced dietary Mg supply due to cereal grain food processing was calculated using the EAR-cut point method as described by (Kumssa et al. 2015).

\section{Results}

Human magnesium requirement

Compared to the World Health Organization (WHO) EAR for $\mathrm{Mg}$, the global level population-weighted EAR (WtdEAR) under the three EAR scenarios increased by $4 \%$ (scenario 1 ), $68 \%$ (scenario 2 ) and 
$107 \%$ (scenario 3) in 1992. In 2011, global WtdEAR increased by $9 \%$ (scenario 1), $77 \%$ (scenario 2) and $118 \%$ (scenario 3) (Table 3). At continental level (Fig. 1), the rise in the WtdEAR in 1992 at various scenarios ranged from 3 to $5 \%$ (scenario 1), $65-72 \%$ (scenario 2) and 103-111\% (scenario 3). In 2011, the rise in WtdEAR at continental level ranged from 8 to $10 \%$ (scenario 1), $73-82 \%$ (scenario 2 ) and $112-124 \%$ (scenario 3) (see Online Resource Supplementary Table 4)).

At regional scale, the median WtdEAR (mg capita ${ }^{-1}$ $\mathrm{d}^{-1}$ ) in 1992 under the three EAR scenarios were 168 (scenario 1), 271 (scenario 2) and 332 (scenario 3). In 2011, the median WtdEAR were 187 (scenario 1), 302 (scenario 2) and 372 (scenario 3) (Fig. 2). The highest median WtdEAR was recorded in Western Europe and the lowest in Middle Africa (Fig. 2). Compared to the estimates made by Kumssa et al. (2015) based on the WHO EAR for Mg with standard reference human body weights, the regional median WtdEAR increased by $2 \%, 64 \%$, and $100 \%$ under scenarios $1-3$, respectively, in 1992 while in 2011, the regional median WtdEAR increased by $8 \%, 70 \%$, and $107 \%$ for scenarios $1-3$, respectively (see Online Resource Supplementary Table 4).

At national scale, in 1992, the highest WtdEAR (mg capita $^{-1} \mathrm{~d}^{-1}$ ) was 190,313 and 385 for EAR scenarios 1-3 respectively in Italy. In the same year, the lowest WtdEAR (mg capita ${ }^{-1} \mathrm{~d}^{-1}$ ) was 151, 238 and 292 for EAR scenarios 1-3 respectively in Yemen. In 2011, the highest WtdEAR (mg capita ${ }^{-1} \mathrm{~d}^{-1}$ ) was 210, 338 and 416 for EAR scenarios 1-3 respectively in United Arab Emirates. In the same year, the lowest WtdEAR (mg capita $^{-1} \mathrm{~d}^{-1}$ ) was 160,253 and 310 for EAR scenarios

Table 3 Global scale estimates of population-weighted estimated average requirements (WtdEAR) for $\mathrm{Mg}\left(\mathrm{mg}\right.$ capita $\left.^{-1} \mathrm{~d}^{-1}\right)$ in 1992 and 2011 at three EAR scenarios. See Table 1 for the descriptions of EAR scenarios. $n=$ number of countries included in the analysis. Numbers in parentheses are the standard deviation of the WtdEAR

\begin{tabular}{llllll}
\hline Year & $n$ & WtdEAR* & Scenario 1 & Scenario 2 & Scenario 3 \\
\hline 1992 & 137 & $166(3)$ & $173(9)$ & $279(17)$ & $343(21)$ \\
2011 & 145 & $173(3)$ & $189(10)$ & $307(19)$ & $377(24)$ \\
\hline
\end{tabular}

*Global scale estimate of WtdEAR based on the World Health Organization (WHO) EAR for Mg (Kumssa et al. 2015) with standard reference body weights and no factor to prevent body $\mathrm{Mg}$ store depletion
1-3 respectively in Niger (Fig. 2 and see Online Resource Supplementary Table 4).

Dietary magnesium supply

The global scale average percentage reductions in the estimated dietary $\mathrm{Mg}$ supply due to cereal grain food processing compared to whole grain cereal (i.e., no processing) were $14 \%$ in 1992 , and $13 \%$ in 2011 at every $25 \%$ processing level and increasing linearly. At $100 \%$ cereal grain food processing, dietary $\mathrm{Mg}$ supply was reduced by 56\% in 1992 and 51\% in 2011 (Table 4).

At continental scale, in 1992 with no cereal grain processing, the median dietary $\mathrm{Mg}$ supply (mg capita ${ }^{-1}$ $\mathrm{d}^{-1}$ ) in descending order was Asia (724), Europe (678), Africa (583), Americas (560), and Oceania (558). In 1992 , at $100 \%$ cereal processing, the reduction in dietary $\mathrm{Mg}$ supply was Asia (63\%), Africa (52\%), Americas (51\%), Europe (40\%) and Oceania (40\%). With no cereal grain processing in 2011, the median dietary $\mathrm{Mg}$ supply (mg capita $\left.{ }^{-1} \mathrm{~d}^{-1}\right)$ in descending order was Asia (776), Europe (686), Africa (680), Americas (618), and Oceania (597). In 2011, at $100 \%$ cereal processing, the reduction in dietary $\mathrm{Mg}$ supply was Asia (57\%), Africa (53\%), Americas (52\%), Europe (44\%) and Oceania (39\%) (Fig. 3 and see online Resource Supplementary Table 4).

At regional scale, at no cereal grain processing the median $\mathrm{Mg}$ supply (mg capita ${ }^{-1} \mathrm{~d}^{-1}$ ) ranged between 861 (North Africa) and 391 (Middle Africa) in 1992. In the same year, at $100 \%$ cereal grain processing, the median $\mathrm{Mg}$ supply (mg capita ${ }^{-1} \mathrm{~d}^{-1}$ ) ranged between 404 (Northern America) and 239 (South-eastern Asia). In 1992, the percentage reduction in the regional median dietary $\mathrm{Mg}$ supply due to $100 \%$ cereal grain processing ranged between 64\% (Southern Asia) and 30\% (Middle Africa). In 2011, at no cereal grain processing the median $\mathrm{Mg}$ supply (mg capita ${ }^{-1} \mathrm{~d}^{-1}$ ) ranged between 960 (North Africa) and 584 (Caribbean). In the same year, at $100 \%$ cereal grain processing, the median Mg supply ( $m g$ capita $^{-1} \mathrm{~d}^{-1}$ ) ranged between 416 (Northern Africa) and 272 (Southern Africa). In 2011, the percentage reduction in the regional median dietary $\mathrm{Mg}$ supply due to $100 \%$ cereal grain processing ranged between 60\% (South-eastern Asia) and 39\% (Australia and New Zealand) (Fig. 4 and see online Resource Supplementary Table 4).

At national level, in 1992, when there was no cereal grain processing, the highest dietary $\mathrm{Mg}$ supply (mg 
EAR scenarios

ii)

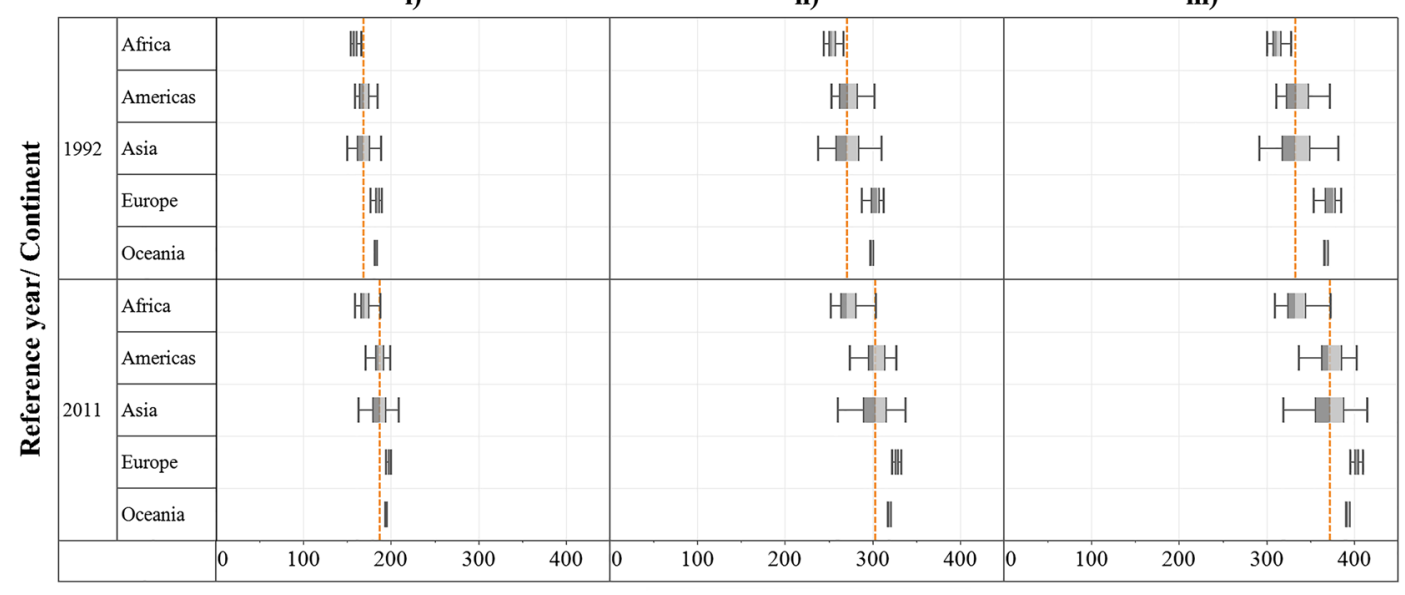

WtdEAR (mg capita $\left.{ }^{-1} \mathbf{d}^{-1}\right)$

Fig. 1 Continental scale estimates of population-weighted estimated average requirements (WtdEAR) for $\mathrm{Mg}\left(\mathrm{mg}\right.$ capita ${ }^{-1} \mathrm{~d}^{-1}$ ) in 1992 and 2011 at three EAR scenarios. Scenario 1 (i), scenario 2 (ii), scenario 3 (iii). See Table 1 for the descriptions of EAR scenarios. Boxes represent the $\mathrm{Mg}$ WtdEAR inter quartile range

capita $^{-1} \mathrm{~d}^{-1}$ ) was recorded in Turkey (1163) and the lowest in Angola (322). At $100 \%$ cereal grain processing, the highest dietary Mg supply (mg capita ${ }^{-1} \mathrm{~d}^{-1}$ ) was recorded in United Arab Emirates (547) and the lowest in Somalia (180). In 2011, when there was no cereal grain processing, the highest dietary $\mathrm{Mg}$ supply ( $\mathrm{mg}$ capita $^{-1} \mathrm{~d}^{-1}$ ) was recorded in Egypt (1077) and the lowest in Somalia (397). At 100\% cereal grain processing, the highest dietary Mg supply (mg capita ${ }^{-1} \mathrm{~d}^{-1}$ ) was recorded in United Arab Emirates (593) and the lowest in Yemen (198) (Fig. 5 and see Online Resource Supplementary Table 4)).

Dietary magnesium deficiency risk

At global scale, the median dietary $\mathrm{Mg}$ deficiency risk was below $2 \%$ at the EAR scenario 1 and cereal grain processing of up to 75\% in 1992 and 2011 (Fig. 6 (i, ad)). At EAR scenario 1 and $100 \%$ cereal grain processing scenario, the median $\mathrm{Mg}$ deficiency risk rose to 5\% in 1992 and 4\% in 2011 (Fig. 6 (i, e)). In 1992, at the EAR scenario $3 \times$ no cereal grain processing, global median dietary $\mathrm{Mg}$ deficiency risk was $3 \%$ and rose to $75 \%$ at EAR scenario $3 \times 100 \%$ cereal grain processing. Similarly, in 2011, global median dietary Mg deficiency risk was $3 \%$ at the EAR scenario $3 \times$ no cereal grain processing (Fig. 6 (iii, a)) but increased to $62 \%$ at the within a continent. Where the grey shade turns lighter represents the median Mg WtdEAR for a continent. Orange broken lines are the overall median $\mathrm{Mg}$ WtdEAR at each scenario and respective reference year

EAR scenario $3 \times 100 \%$ cereal grain processing (Fig. 6 (iii, e) and see Online Resource Supplementary Table 4).

At continental scale, the median dietary Mg deficiency risk was $\leq 2 \%$ for all continents at the EAR scenario 1 and cereal grain processing of up to $50 \%$ in 1992 and 2011 (Fig. 7 (a-c, i)). At EAR scenario 1 and 100\% cereal grain processing scenario, the median $\mathrm{Mg}$ deficiency risk ranged from 3\% (Europe and Oceania) to 7\% (Americas and Asia) in 1992 (Fig. 7, (e, i)). In 2011, at EAR scenario 1 and $100 \%$ cereal grain processing scenario, the median $\mathrm{Mg}$ deficiency risk ranged from $3 \%$ (Africa, Europe and Oceania) to 6\% (Americas) (Fig. 7, (i, e)). At the EAR scenario $2 \times 100 \%$ cereal grain processing, the highest median $\mathrm{Mg}$ deficiency risk (50\%) was recorded in Asia in 1992 (53\%) and 2011 $(50 \%)$ (Fig. 7, (ii, e)). At the EAR scenario $3 \times 100 \%$ cereal grain processing, the highest median $\mathrm{Mg}$ deficiency risk was recorded in Americas in 1992 (84\%) and 2011 (82\%) (Fig. 7, (iii, e)).

At regional scale, the median dietary $\mathrm{Mg}$ deficiency risk was below $\leq 2 \%$ in all regions at the EAR scenario 1 and cereal grain processing of up to $50 \%$ in 1992 and 2011 (Fig. 8). In 1992, At EAR scenario $1 \times 100 \%$ cereal grain processing scenario, the median $\mathrm{Mg}$ deficiency risk ranged between $2 \%$ (Northern America) and 10\% (South-eastern Asia) (Fig. 8). In 2011, At EAR scenario $1 \times 100 \%$ cereal grain processing scenario, the median $\mathrm{Mg}$ deficiency risk ranged between $1 \%$ 


\section{EAR scenarios}

i)

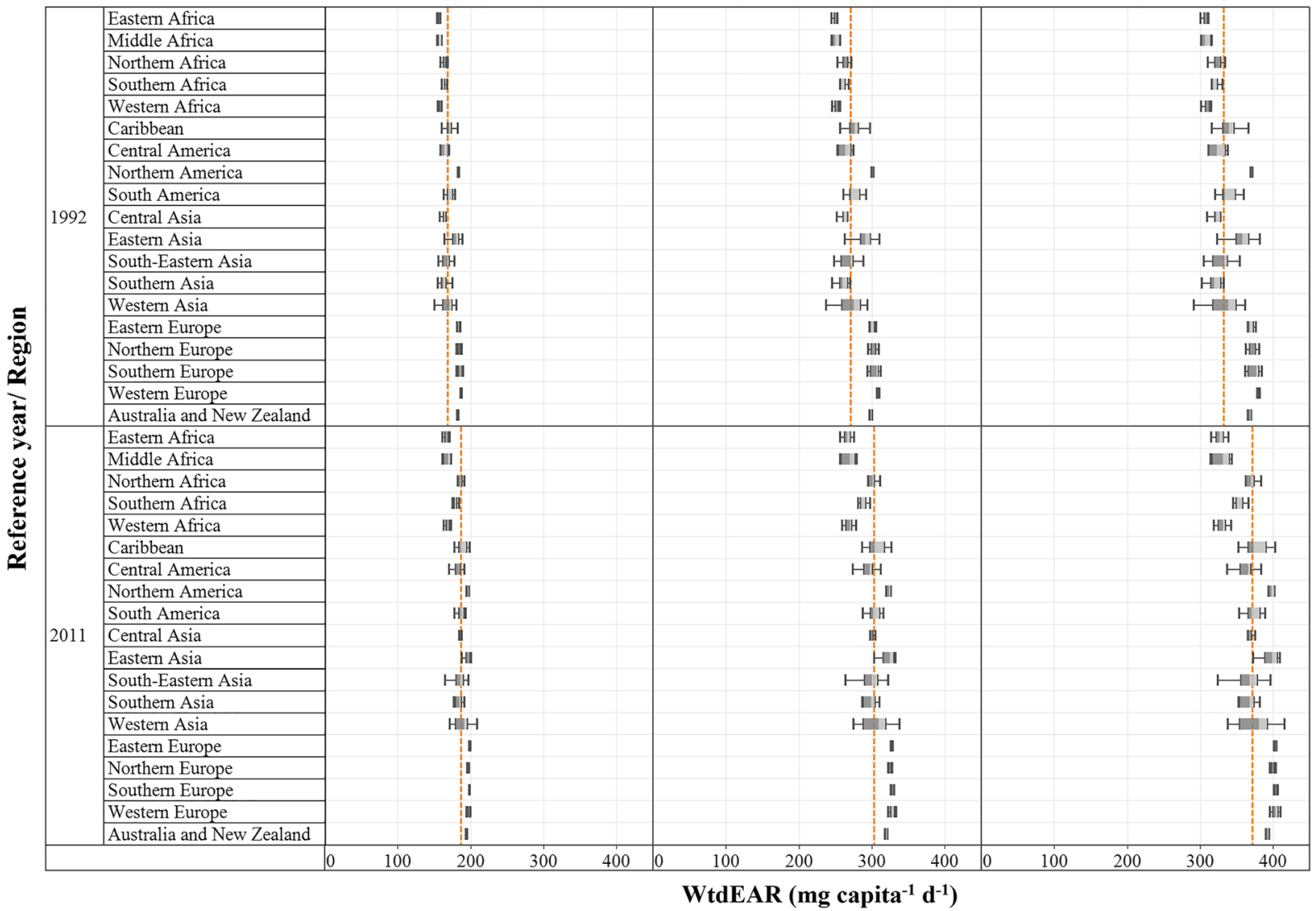

Fig. 2 Regional scale estimates of population-weighted estimated average requirements (WtdEAR) for $\mathrm{Mg}\left(\mathrm{mg}_{\text {capita }}{ }^{-1} \mathrm{~d}^{-1}\right)$ in 1992 and 2011 at three EAR scenarios. Scenario 1 (i), scenario 2 (ii), scenario 3 (iii). See Table 1 for the descriptions of EAR scenarios. Boxes represent the $\mathrm{Mg}$ WtdEAR inter quartile range within a

(Northern Africa) and 10\% (Southern Africa). In 1992, at EAR scenario $3 \times 100 \%$ cereal grain processing scenario, the median $\mathrm{Mg}$ deficiency risk ranged between 38\% (Northern America) and 92\% (Southern Asia). In 2011, At EAR scenario $3 \times 100 \%$ cereal grain processing scenario, the median $\mathrm{Mg}$ deficiency risk ranged

Table 4 Global scale estimates of human dietary Mg supply (mg capita $^{-1} \mathrm{~d}^{-1}$ ) in 1992 and 2011 at five cereal grain processing scenarios. See online Resource Supplementary Table 4 for the region. Where the grey shade turns lighter represents the median $\mathrm{Mg}$ WtdEAR for a region. Orange broken lines are the overall median Mg WtdEAR at each scenario and respective reference year

between 34\% (Northern Africa) and 91\% (Southern Africa) (see Figs. 9, and 10 and Online Resource Supplementary Table 4).

At national level, at EAR scenario $1 \times$ no cereal grain processing, the dietary $\mathrm{Mg}$ deficiency risk ranged between $0.03 \%$ (Turkey) and 2\% (Angola) in 1992, and

\begin{tabular}{|c|c|c|c|c|c|c|}
\hline \multirow[t]{2}{*}{ Year } & \multirow[t]{2}{*}{$\mathrm{n}$} & \multicolumn{5}{|c|}{ Cereal grain processing scenarios } \\
\hline & & Scenario 1 & Scenario 2 & Scenario 3 & Scenario 4 & Scenario 5 \\
\hline 1992 & 137 & $698(100)$ & $600(82)$ & $502(68)$ & $404(61)$ & $306(61)$ \\
\hline 2011 & 145 & $758(118)$ & $661(103)$ & $564(91)$ & $468(82)$ & $371(78)$ \\
\hline
\end{tabular}

descriptions of cereal grain processing scenarios. $n=$ number of countries included in the analysis. Numbers in parentheses are the standard deviation of the Mg supply 
Cereal grain food processing scenarios

a) b)

c) d)

d) e)

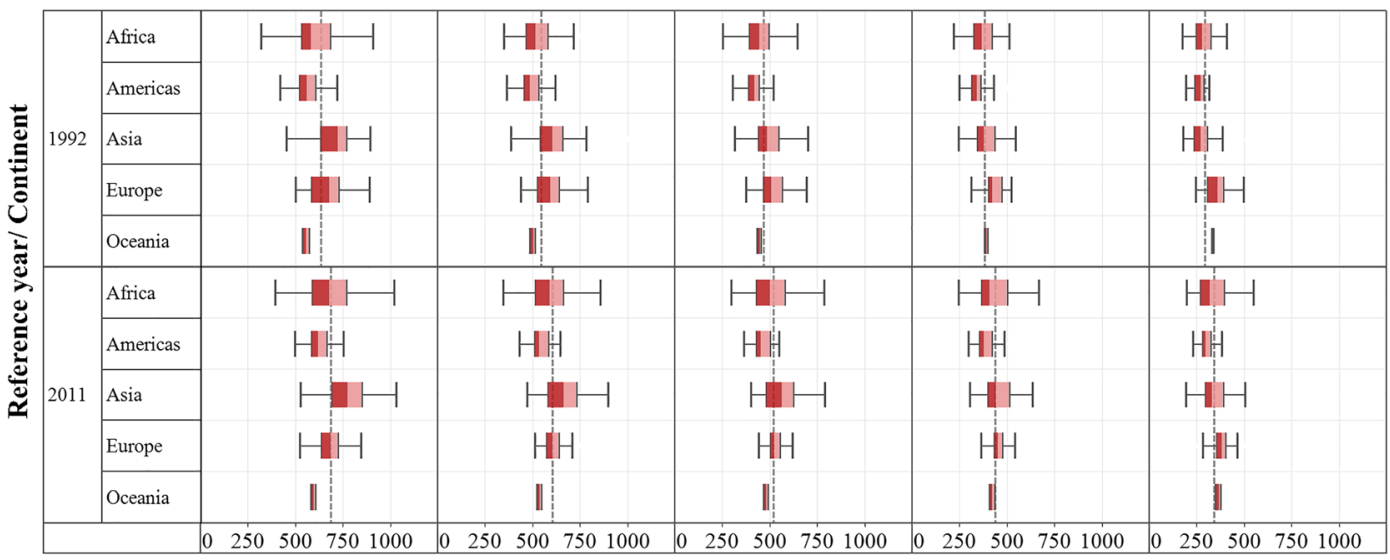

Mg supply (mg capita $\left.{ }^{-1} \mathrm{~d}^{-1}\right)$

Fig. 3 Continental scale estimates of dietary Mg supply (mg capita $^{-1} \mathrm{~d}^{-1}$ ) in 1992 and 2011 at five scenarios of cereal grain processing. No processing (a), 25\% processing (b), $50 \%$ processing (c), $75 \%$ processing (d) and $100 \%$ processing (e). Boxes represent the $\mathrm{Mg}$ supply inter quartile range within a continent. Where the red shade turns lighter represents the median for each continent. Grey broken lines are the overall median $\mathrm{Mg}$ supply at each scenario and respective year

Cereal grain food processing scenarios

a) b)

c)

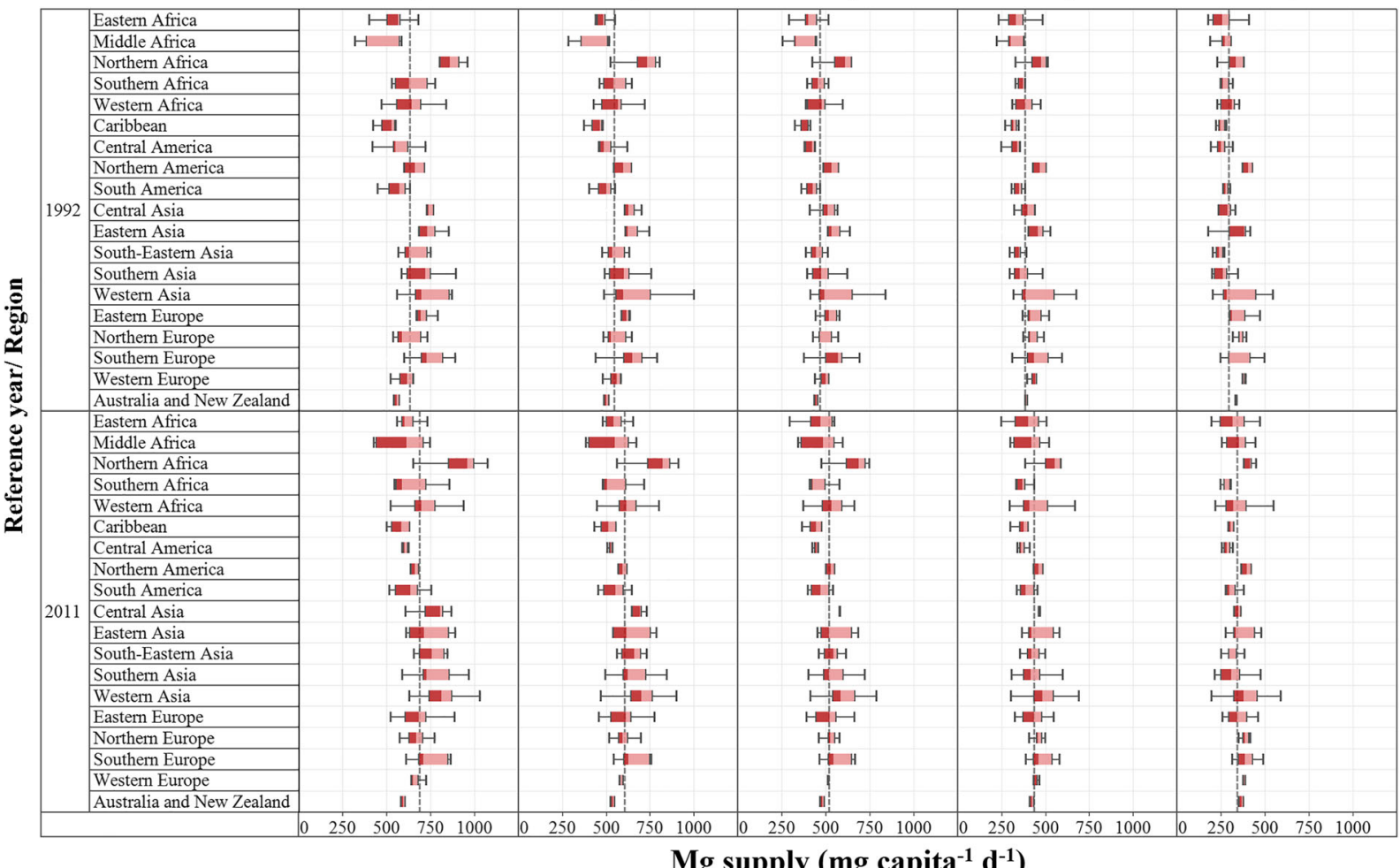

Fig. 4 Regional scale estimates of dietary Mg supply (mg capita ${ }^{-1}$ $\mathrm{d}^{-1}$ ) in 1992 and 2011 at five scenarios of cereal grain processing. No processing (a), 25\% processing (b), 50\% processing (c), $75 \%$ processing (d) and $100 \%$ processing (e). Boxes represent the $\mathrm{Mg}$ supply inter quartile range within a region. Where the red shade turns lighter represents the median for a region. Grey broken lines are the overall median $\mathrm{Mg}$ supply at each scenario and respective year 


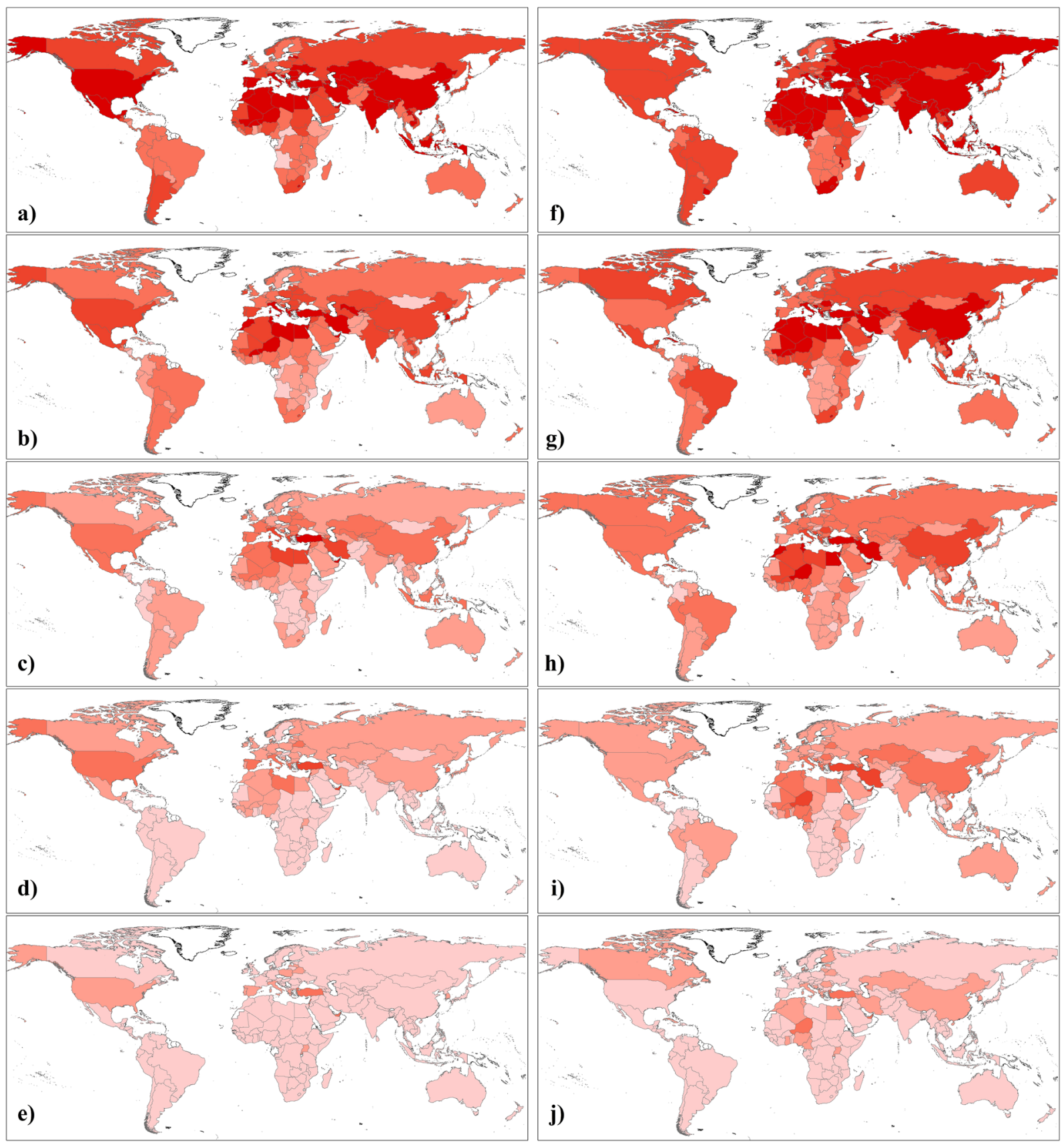

\section{$180-400 \square 401-500 \square 501-600 \square 601-700 \square>700 \square$ No data}

Fig. 5 Estimates of national level dietary $\mathrm{Mg}$ supply $\left(\mathrm{mg} \mathrm{capita}^{-1} \mathrm{~d}^{-1}\right.$ ) at five scenarios of cereal grain processing (no processing, $25 \%$, $50 \%, 75 \%$ and $100 \%$ processing, respectively) in 1992 (a-e) and 2011 (f-j)

$0.04 \%$ (Niger) and 1\% (Somalia) in 2011. At EAR scenario $1 \times 100 \%$ cereal grain processing, the dietary $\mathrm{Mg}$ deficiency risk ranged between $0.4 \%$ (Lebanon) and $36 \%$ (Mongolia) in 1992, and $0.2 \%$ (Niger) and $30 \%$ (Yemen) in 2011. At EAR scenario $3 \times$ no cereal grain processing, the dietary $\mathrm{Mg}$ deficiency risk ranged between $0.2 \%$ (Turkey) and 40\% (Angola) in 1992, and $0.3 \%$ (Niger) and $21 \%$ (Somalia) in 2011. At EAR scenario $3 \times 100 \%$ cereal grain processing, the dietary $\mathrm{Mg}$ deficiency risk ranged between $8 \%$ (Lebanon) and 
Cereal grain food processing scenarios

a)

b)

c)

d)

e)

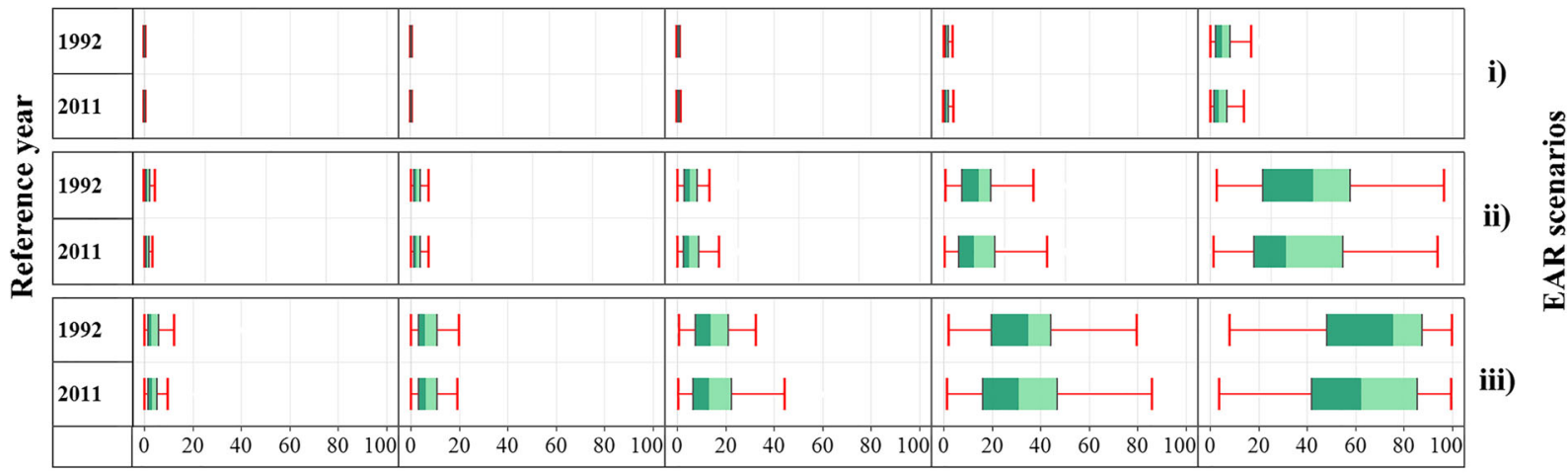

Mg deficiency risk (\%)

Fig. 6 Global scale estimates of dietary $\mathrm{Mg}$ deficiency risk (\%) in 1992 and 2011. Columns represent five scenarios of cereal grain processing: no processing (a), 25\% processing (b), 50\% processing (c), $75 \%$ processing (d) and $100 \%$ processing (e). Rows represent the three EAR scenarios: (i), scenario 2 (ii), scenario 3 (iii). See Table 1 for the descriptions of EAR scenarios. Boxes represent the inter quartile range of the $\mathrm{Mg}$ deficiency risk at the respective scenario combination and year. Where the green shade turns lighter represents the median

\section{Cereal grain food processing scenarios}

a)

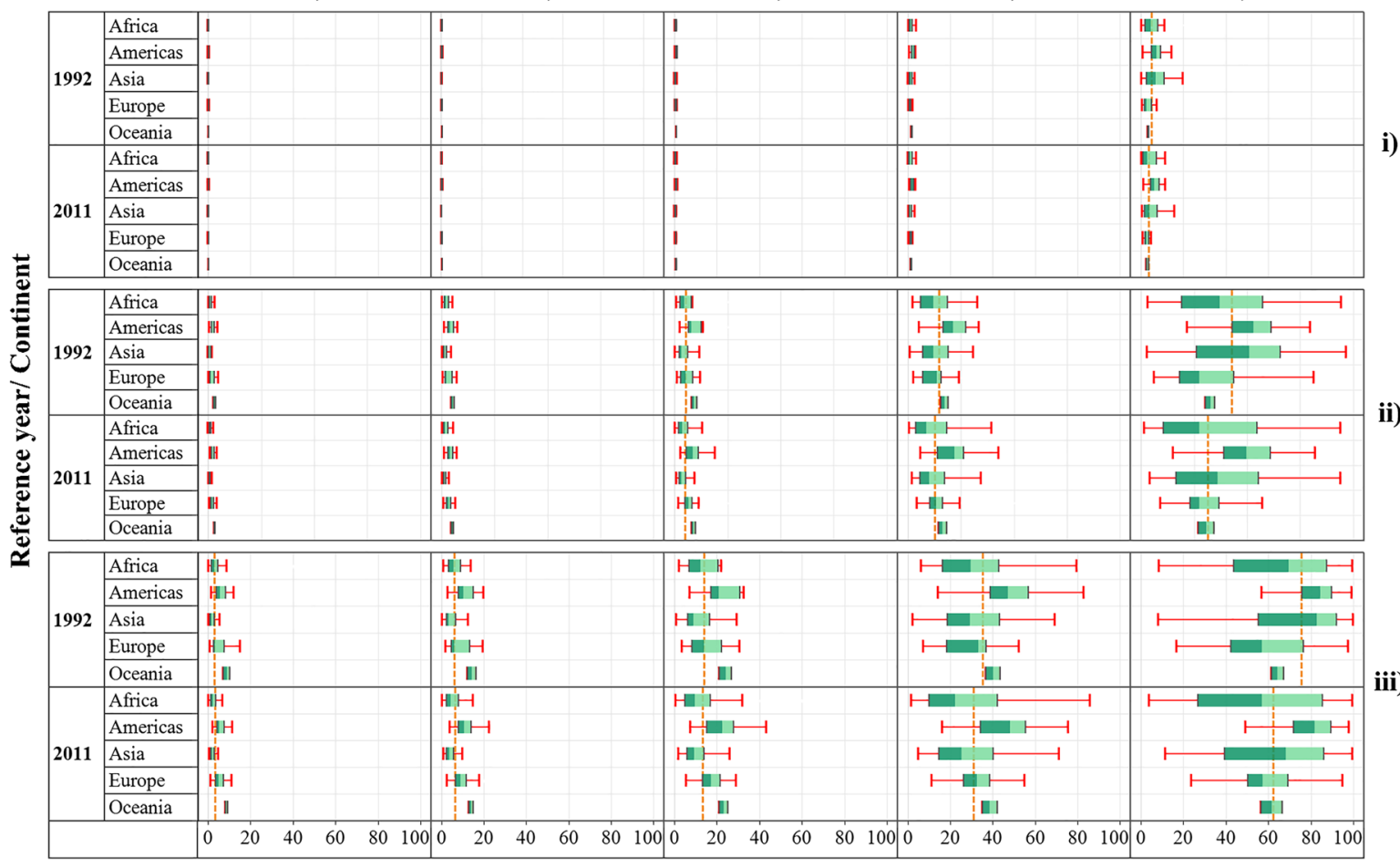

i)

ii)
Fig. 7 Continental scale estimates of dietary $\mathrm{Mg}$ deficiency risk (\%) in 1992 and 2011. Columns represent five scenarios of cereal grain processing: no processing (a), $25 \%$ processing (b), $50 \%$ processing (c), $75 \%$ processing (d) and $100 \%$ processing (e). Rows represent the three EAR scenarios: scenario 1 (i), scenario 2 (ii), scenario 3 (iii). See Table 1 for the descriptions of EAR scenarios. Boxes represent inter quartile range of the $\mathrm{Mg}$ deficiency risk within a continent. Where the green shade turns lighter represents the median for a continent. Orange broken lines are the overall median $\mathrm{Mg}$ deficiency risk at the intersection of cereal grain processing and EAR scenario for the respective year 
Cereal grain food processing scenarios

a)

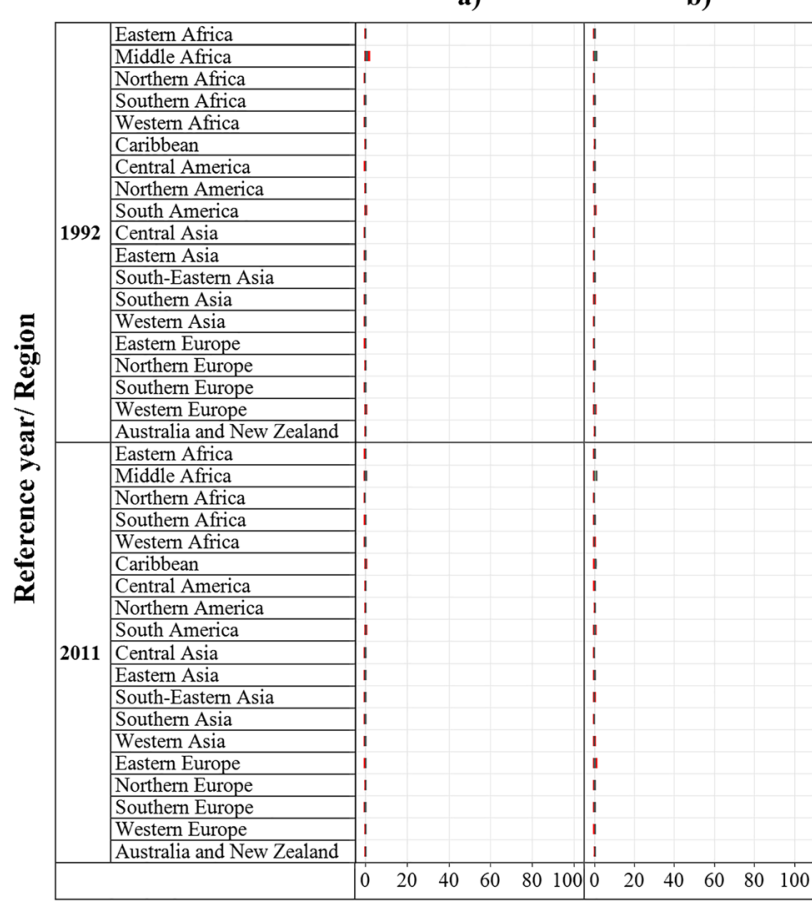

c)

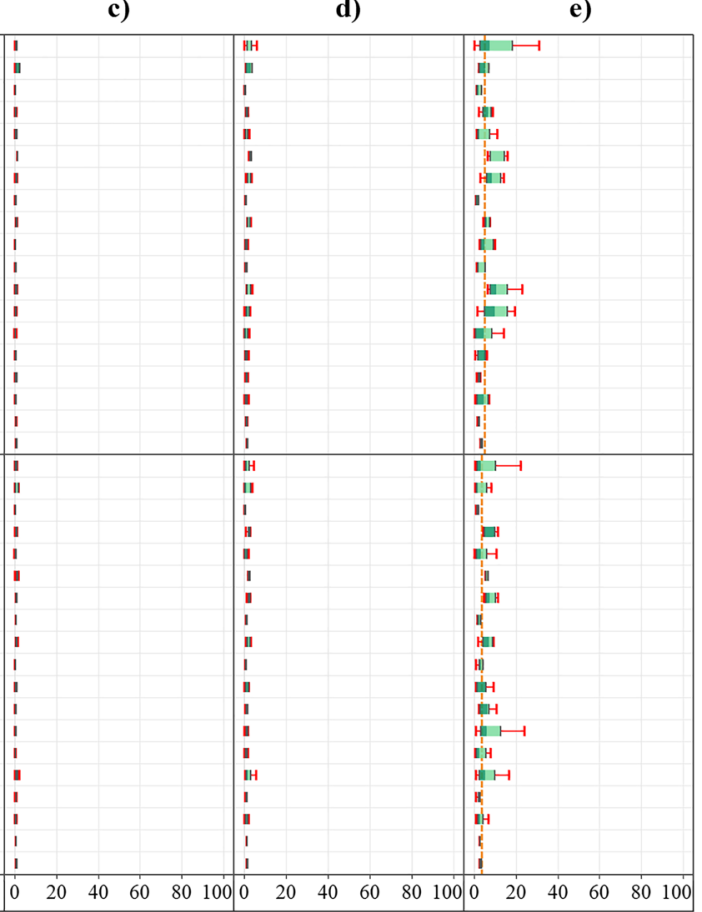

Fig. 8 Regional scale estimates of dietary Mg deficiency risk (\%) in 1992 and 2011, EAR scenario 1. See Table 1 for the descriptions of EAR scenarios. Columns represent five scenarios of cereal grain processing: no processing (a), 25\% processing (b), 50\% processing (c), $75 \%$ processing (d) and $100 \%$ processing (e). Boxes represent the inter quartile range of the $\mathrm{Mg}$ deficiency risk within

100\% (Mongolia) in 1992, and 4\% (Niger) and 99\% (Somalia) in 2011 (see Figs. 11, and 12 and Online Resource Supplementary Table 4).

\section{Discussion}

Global human dietary $\mathrm{Mg}$ supply per person grew 9\% between 1992 and 2011 as did human Mg requirement, the latter due to increases in average human body weights and adjustments for body $\mathrm{Mg}$ store depletion. The rise of $\mathrm{Mg}$ requirement between 1992 and 2011 reflects changes in human population sizes, rise in body weights experienced in all countries, plus changes in age profile of populations (Lutz et al. 2008) as younger humans have lower $\mathrm{Mg}$ requirement than do adults.

The dietary Mg supply appears adequate for body weight corrected human nutritional needs at all levels of

\section{Mg deficiency risk (\%)}

a region. Where the green shade turns lighter represents the median for a region. Orange broken lines are the overall median $\mathrm{Mg}$ deficiency risk at the intersection of cereal grain processing and EAR scenario for the respective year. See Online Resource Supplementary Table 4 for further information

grain processing loss, even at $100 \%$, with risks of $\mathrm{Mg}$ deficiency $<10 \%$ at global, continental and regional levels and no more than $30 \% \mathrm{Mg}$ deficiency risk at the national level. However, the risk of $\mathrm{Mg}$ deficit increases substantially when estimates of $\mathrm{Mg}$ requirement include factors to prevent depletion of body $\mathrm{Mg}$ stores, especially when grain $\mathrm{Mg}$ processing losses begin to exceed $50 \%$ (see Fig. 6). From where do these estimates of $\mathrm{Mg}$ requirement for conservation of body $\mathrm{Mg}$ stores arise?

Magnesium is primarily an intracellular cation having several vital cellular functions. At the sub-cellular level, $\mathrm{Mg}$ influences contractile proteins, modulates ion channels, acts as an essential cofactor in the activation of adenosine triphosphatase (ATPase), controls metabolic regulation of energy-dependent cytoplasmic and mitochondrial pathways, regulates glycolysis, influences deoxyribonucleic acid synthesis and transcription, induces protein synthesis and promotes cell growth (Romani 2011). 


\section{Cereal grain food processing scenarios}

a)

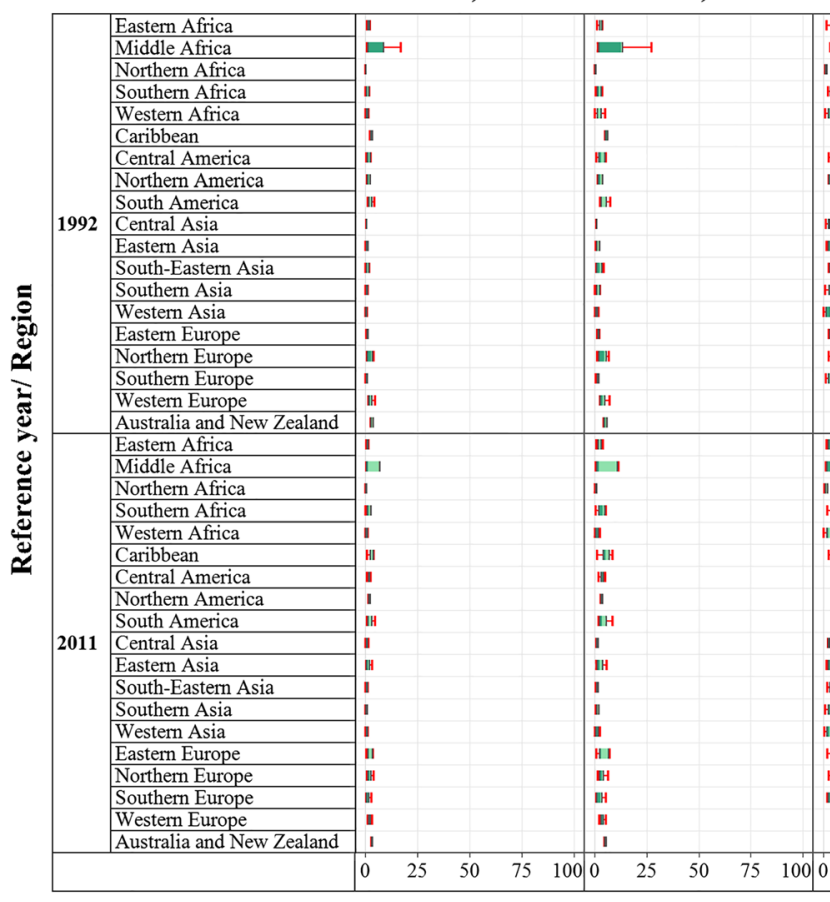

c)

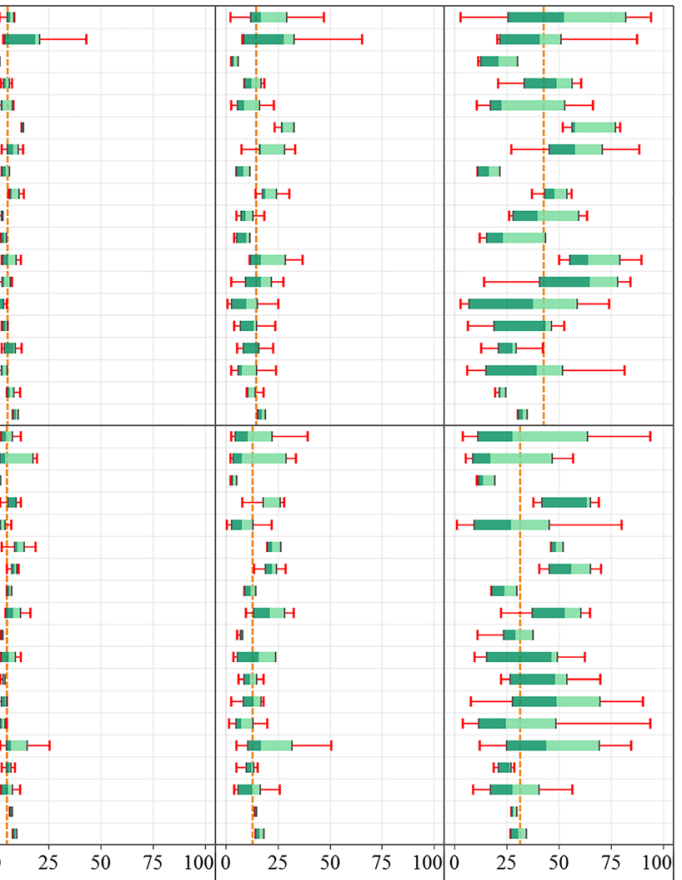

ii)
Fig. 9 Regional scale estimates of dietary Mg deficiency risk (\%) in 1992 and 2011, EAR scenario 2. See Table 1 for the descriptions of EAR scenarios. Columns represent five scenarios of cereal grain processing: no processing (a), 25\% processing (b), 50\% processing (c), 75\% processing (d) and $100 \%$ processing (e). Boxes represent the inter quartile range of the $\mathrm{Mg}$ deficiency risk within
Mg deficiency risk (\%)

a region. Where the green shade turns lighter represents the median for a region. Orange broken lines are the overall median $\mathrm{Mg}$ deficiency risk at the intersection of cereal grain processing and EAR scenario for the respective year. See Online Resource Supplementary Table 4 for further information

(Wallach 1988). Mean daily Mg losses ranging between -150 and $+150 \mathrm{mg} \mathrm{d}^{-1}$ in human adults are often seen in the types of $\mathrm{Mg}$ balance studies chosen to set the EARs for Mg (Seeling 1964; Hunt and Johnson 2006). A person in slight but continuous negative $\mathrm{Mg}$ balance as little as -3 to $-10 \mathrm{mg} \mathrm{d}^{-1}$ can build cumulative $\mathrm{Mg}$ losses of -1095 to $-3650 \mathrm{mg} \mathrm{yr}^{-1}$ and -5475 to $-18,250 \mathrm{mg} 5 \mathrm{yrs}^{-1}$. Considering the adult human body contains about $25 \mathrm{~g} \mathrm{Mg}$ (WHO and FAO 2004; Volpe 2012), these are substantial Mg losses representing depletion of $23 \%$ to $73 \%$ of whole body $\mathrm{Mg}$ in five years and would be expected to register as substantial loss of body Mg stores in a Mg load test (Wallach 1988; Cohen 2000), i.e. as CLMD. Translocation of body Mg stores has not been a factor in determining $\mathrm{Mg}$ requirements. Data from both older (Seeling 1964) and newer (Hunt and Johnson 2006) sets of human Mg balance studies show that an intake of 6-7 $\mathrm{mg} \mathrm{kg}^{-1} \mathrm{BW}$ is necessary for all healthy adults studied to be in neutral or positive $\mathrm{Mg}$ CLMD (Elin 2010; Elin 2012) showing decreased Mg 


\section{Cereal grain food processing scenarios}

a)

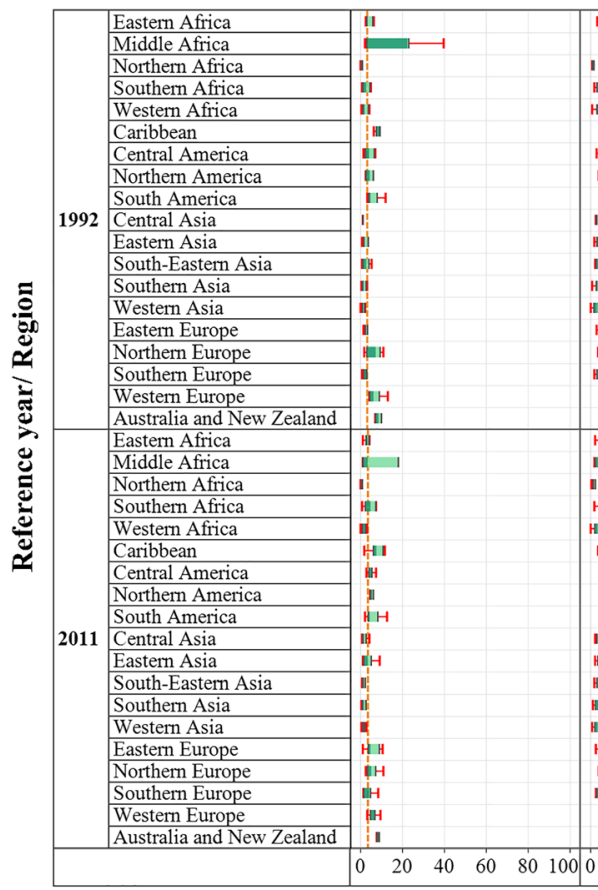

b)

c)

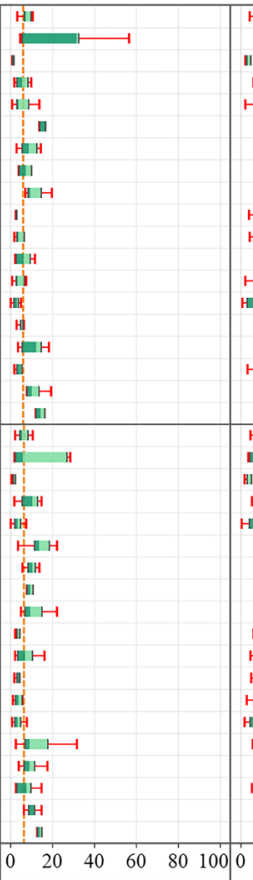

d)

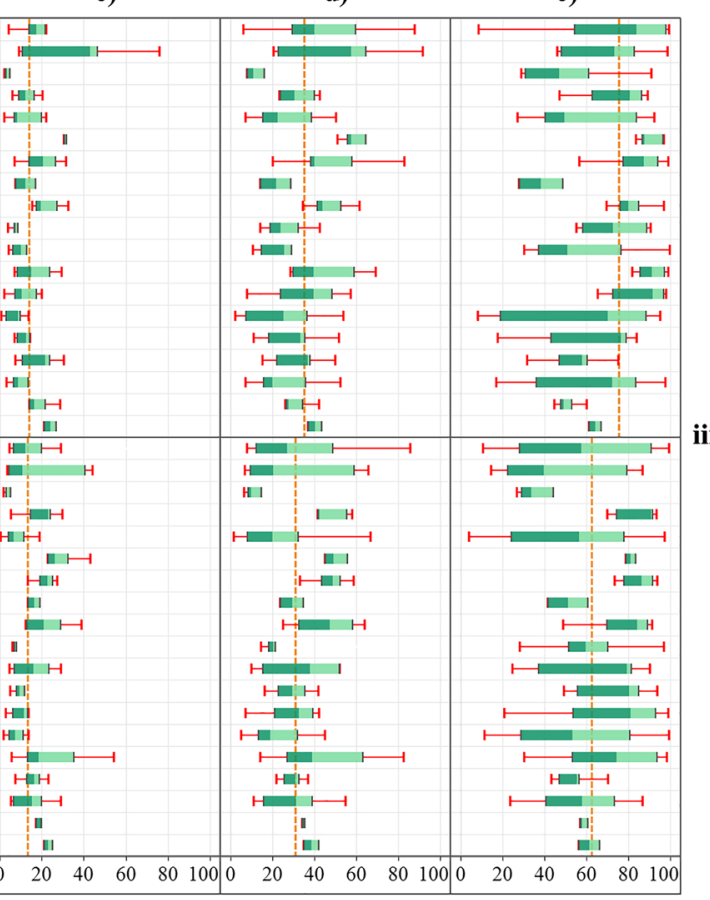

Fig. 10 Regional scale estimates of dietary Mg deficiency risk (\%) in 1992 and 2011, EAR scenario 3. See Table 1 for the descriptions of EAR scenarios. Columns represent five scenarios of cereal grain processing: no processing (a), 25\% processing (b), $50 \%$ processing (c), $75 \%$ processing (d) and $100 \%$ processing (e). Boxes represent the inter quartile range of the $\mathrm{Mg}$ deficiency risk

balance (Nielsen and Johnson 2017), the range necessary to prevent depletion of $\mathrm{Mg}$ body stores.

We have used the $\mathrm{Mg}$ Factor of $6.5 \mathrm{mg} \mathrm{kg}^{-1} \mathrm{~d}^{-1}$ for adults and proportional factors for other ages for our low estimate of $\mathrm{Mg}$ requirement to prevent negative $\mathrm{Mg}$ balance and thus depletion of body Mg stores (Scenario 2). Since $\mathrm{Mg}$ requirement rises with stress, we also used the factor $8 \mathrm{mg} \mathrm{kg}^{-1} \mathrm{~d}^{-1}$ for adults and proportionally for other ages for scenario 3, a high estimate to prevent depletion of body $\mathrm{Mg}$ stores. These factors are conservative considering the only published estimate for adult $\mathrm{Mg}$ requirement factor necessary to prevent negative $\mathrm{Mg}$ balance range from 7 to $10 \mathrm{mg} \mathrm{kg}^{-1} / \mathrm{d}^{-1}$ (Seeling 1964). At this time, no national or international publications setting $\mathrm{Mg}$ requirements for humans are quantified to prevent negative Mg balance (Great Britain Panel on Dietary Reference Values 1991; Institute of Medicine 1997; WHO and FAO 2003; EFSA Panel on Dietetic Products Nutrition and Allergies 2015).

\section{Mg deficiency risk (\%)}

within a region. Where the green shade turns lighter represents the median for a region. Orange broken lines are the overall median $\mathrm{Mg}$ deficiency risk at the intersection of cereal grain processing and EAR scenario for the respective year. See Online Resource Supplementary Table 4 for further information

Whole grains with their potentially high phytate and other fibre components might be expected to lower $\mathrm{Mg}$ absorption as phytate added to refined wheat flour significantly lowers fractional $\mathrm{Mg}$ absorption (Bohn et al. 2004). However, human studies comparing health effects of refined and whole grain diets show that whole grains in diets provide higher $\mathrm{Mg}$ and fibre intakes (Katcher et al. 2008) and lower risks of both diabetes and heart disease (McCarty 2005; Jensen et al. 2006). Whole grain diets also appear to be cardioprotective when compared with refined grain diets (Kristensen et al. 2012) possibly due to a protection in insulin sensitivity (McCarty 2005) while providing improved glycaemic control and lipid profiles (Jensen et al. 2006).

Use of WHO RNIs is a conservative approach as they present the lowest of all estimates of human $\mathrm{Mg}$ requirements (EFSA Panel on Dietetic Products Nutrition and Allergies 2015) none of which have been corrected for rising human body weights. Nonetheless, even with 


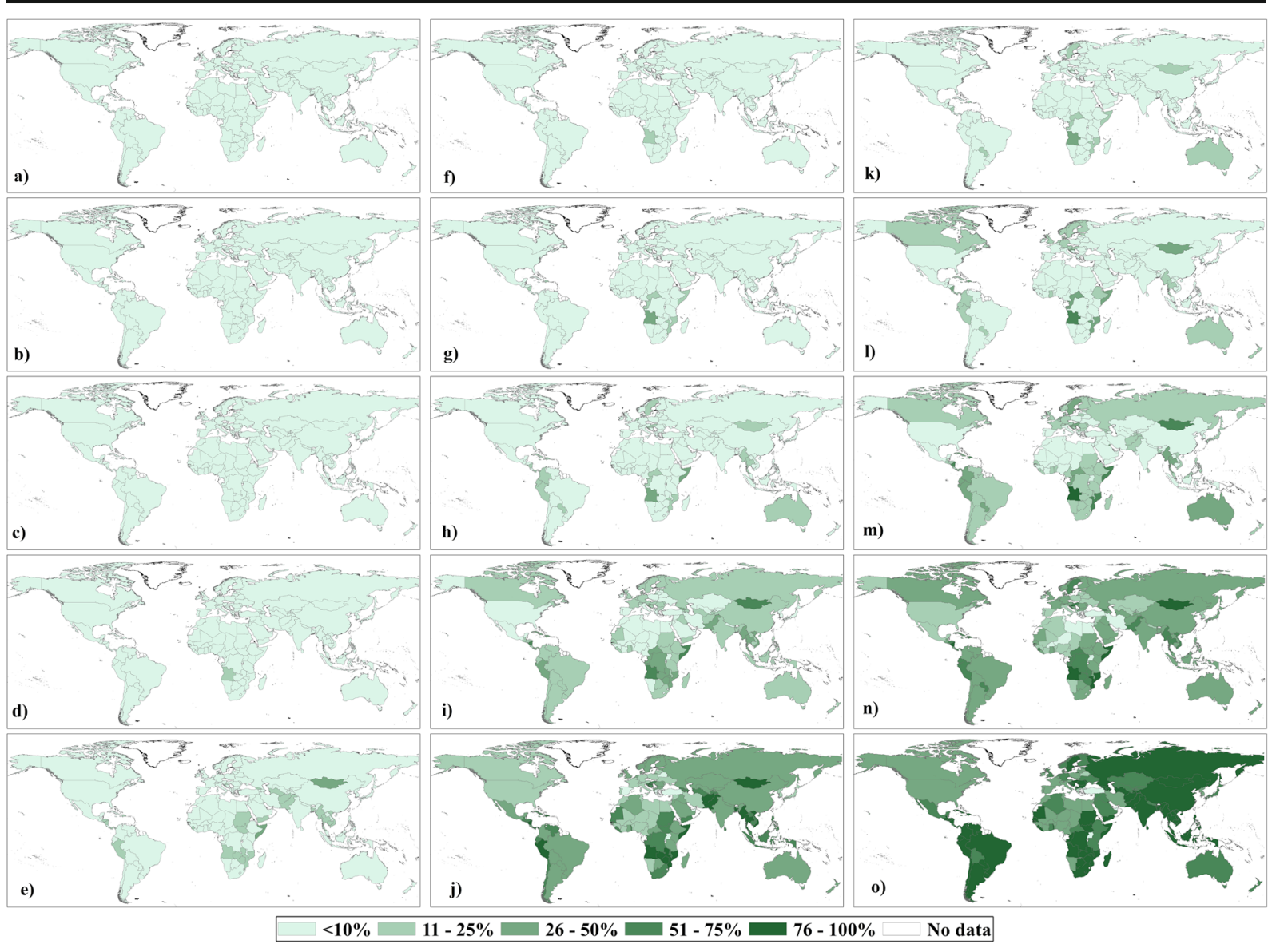

Fig. 11 Estimates of national level dietary $\mathrm{Mg}$ deficiency risk (\%) under three EAR scenarios (scenario 1-3, left to right columns) and five scenarios of cereal grain food processing (top to bottom rows representing whole, $25 \%, 50 \%, 75 \%$ and $100 \%$, respectively) in 1992

these conservative $\mathrm{Mg}$ requirements, this approach still shows that high levels of grain processing lead to high levels of $\mathrm{Mg}$ deficit and with it the risk of chronic diseases of Man.

\section{Caveats of the study}

For the EAR scenarios, body weight data for children (5-19 yrs) was derived from an arithmetic mean of the BMI for the 200 countries which was not weighted by country populations. For adult mean global BW calculations, adult heights were arithmetic means of the 200 countries, height at age 18 for men and women. However, the EAR for each scenario had later been weighted by the population sizes of the respective age/gender in each country included in this study resulting in a population weighted $\mathrm{Mg}$ EAR. To estimate $\mathrm{Mg}$ processing losses, we considered only grain processing. There may be other $\mathrm{Mg}$ processing losses due to processing of cane and beet to sugar and/or oilseeds to oils.

We studied human $\mathrm{Mg}$ balance data and hopefully made educated estimates of human $\mathrm{Mg}$ requirement to offset depletion of body $\mathrm{Mg}$ stores. But, there are no balance studies that have measured CLMD in more than a few subjects nor are there measures of the percent of CLMD in any world populations. We do not know if these factors will prevent or correct CLMD depleted body $\mathrm{Mg}$ stores as direct research of this question is currently inadequate to make this determination. Such work needs to be done in order to accurately adjust the $\mathrm{Mg}$ RNI factors to both prevent and correct depletion of body $\mathrm{Mg}$ stores.

The WHO RNIs assume a coefficient of variation of $10 \%$. In this study, EAR $=\mathrm{RNI} / 1.2$ was used to estimate $\mathrm{Mg}$ requirements of $50 \%$ of the healthy individuals in a population. However, the actual coefficient of variation of human $\mathrm{Mg}$ requirement 


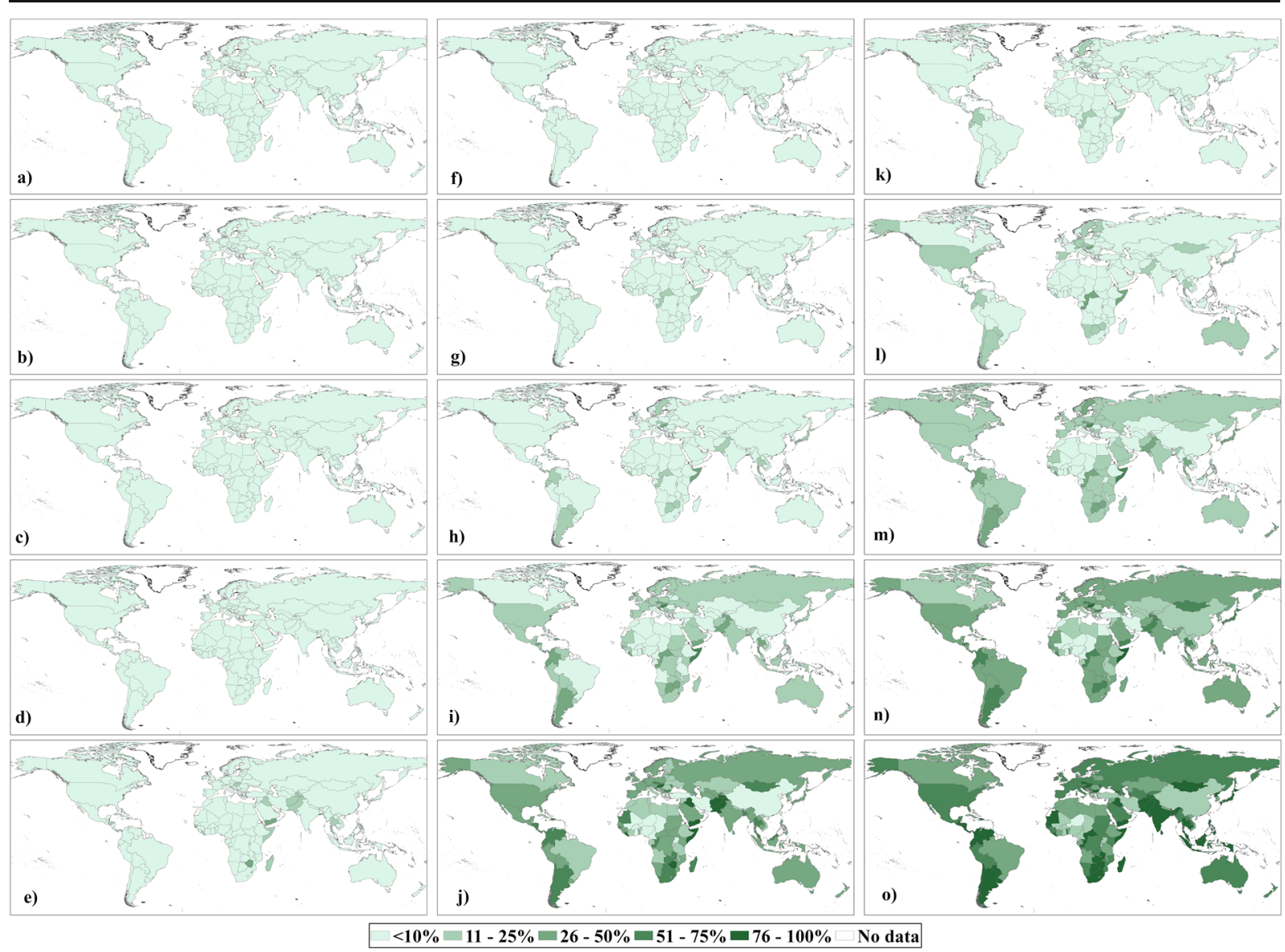

Fig. 12 Estimates of national level dietary Mg deficiency risk (\%) under three EAR scenarios (scenario 1-3, left to right columns) and five cereal grain food processing scenarios (top to bottom rows representing whole, 25\%, 50\%, 75\% and 100\%, respectively) in 2011

has not been measured. Besides, WHO RNIs assume no extra $\mathrm{Mg}$ requirement for pregnancy even though $\mathrm{Mg}$ is associated with pre-mature birth and low birth weight (Tsang and Oh 1970; Takaya et al. 2006; Marret et al. 2008). We added no factor for pregnancy, but assumed a standard rise in body weight which resulted in increased RNIs and EARs for pregnancy in our calculations.

Additional limitation of this study is the use of food composition data from the United States Department of Agriculture Nutrient Data Laboratory to determine dietary $\mathrm{Mg}$ supply in 145 agronomically and geologically diverse countries. This may result in either over or under estimation of the $\mathrm{Mg}$ concentration in the various food items grown in these countries and dietary $\mathrm{Mg}$ supply to the population of those countries. Future research works to develop national and sub-national food composition tables are recommended.

\section{Conclusions}

Global dietary Mg Supply appears to adequately meet human $\mathrm{Mg}$ requirement, even given the global obesity epidemic and rising human body weights. But high $\mathrm{Mg}$ losses due to grain processing start to show noteworthy risks of potential $\mathrm{Mg}$ deficit due to chronic depletion of body $\mathrm{Mg}$ stores in populations consuming diets with $50 \%+$ grain processing. These findings have ramifications for the global spread and development of the major chronic, non-communicable diseases which are associated with low nutritional $\mathrm{Mg}$.

Open Access This article is licensed under a Creative Commons Attribution 4.0 International License, which permits use, sharing, adaptation, distribution and reproduction in any medium or format, as long as you give appropriate credit to the original author(s) and the source, provide a link to the Creative Commons licence, and indicate if changes were made. The images or other third party 
material in this article are included in the article's Creative Commons licence, unless indicated otherwise in a credit line to the material. If material is not included in the article's Creative Commons licence and your intended use is not permitted by statutory regulation or exceeds the permitted use, you will need to obtain permission directly from the copyright holder. To view a copy of this licence, visit http://creativecommons.org/licenses/by/4.0/.

\section{References}

Abu-Saad K, Shai I, Kaufman-Shriqui V, German L, Vardi H, Fraser D (2009) Bread type intake is associated with lifestyle and diet quality transition among Bedouin Arab adults. Br J Nutr 102:1513-1522. https://doi.org/10.1017 /S0007114509990675

Alfrey AC, Miller NL, Butkus D (1974) Evaluation of body magnesium stores. J Lab Clin Med 84:153-162

Azab M, Al-Shudifat A-E, Agraib L, Allehdan S, Tayyem R (2019) Does micronutrients intake modulate the risk of coronary heart disease? Nutr Food Sci 49:368-380. https://doi. org/10.1108/NFS-06-2018-0176

Barbagallo M, Dominguez LJ (2015) Magnesium and type 2 diabetes. World J Diabetes 6:1152-1157. https://doi. org/10.4239/wjd.v6.i10.1152

Bixby H, Bentham J, Zhou B, Di Cesare M, Paciorek CJ, Bennett JE, Taddei C, Stevens GA, Rodriguez-Martinez A, CarrilloLarco RM, Khang Y-H, Sorić M, Gregg EW, Miranda JJ, Bhutta ZA, Savin S, Sophiea MK, Iurilli MLC, Solomon BD, Cowan MJ, Riley LM, Danaei G, Bovet P, Chirita-Emandi A, Hambleton IR, Hayes AJ, Ikeda N, Kengne AP, Laxmaiah A, Li Y, McGarvey ST, Mostafa A, Neovius M, Starc G, Zainuddin AA, Abarca-Gómez L, Abdeen ZA, Abdrakhmanova S, Abdul Ghaffar S, Abdul Hamid Z, Abubakar Garba J, Abu-Rmeileh NM, Acosta-Cazares B, Adams RJ, Aekplakorn W, Afsana K, Agdeppa IA, Aguilar-Salinas CA, Agyemang C, Ahmad MH, Ahmad NA, Ahmadi N, Ahmadvand A, Ahrens W, Ajlouni K, AlBuhairan F, AlDhukair S, Al-Hazzaa HM, Ali MM, Ali O, Aa A, Al-Othman AR, Al-Raddadi R, Alvarez-Pedrerol M, Aly E, Amarapurkar DN, Amouyel P, Amuzu A, Andersen LB, Anderssen SA, Ängquist LH, Anjana RM, Ansari-Moghaddam A, Aounallah-Skhiri H, Araújo J, Ariansen I, Aris T, Arku RE, Arlappa N, Aryal KK, Aspelund T, Assah FK, Assunção MCF, Aung MS, Auvinen J, Avdicová M, Azevedo A, Azizi F, Azmin M, Babu BV, Baharudin A, Bahijri S, Baker JL, Balakrishna N, Bamoshmoosh M, Banach M, Bandosz P, Banegas JR, Barbagallo CM, Barceló A, Barkat A, Barros AJD, Barros MVG, Bata I, Batieha AM, Batista RL, Battakova Z, Batyrbek A, Baur LA, Beaglehole R, Bel-Serrat S, Ben Romdhane H, Benedics J, Benet M, Berkinbayev S, Bernabe-Ortiz A, Bernotiene G, Bettiol H, Bhagyalaxmi A, Bharadwaj S, Bhargava SK, Bi H, Bi Y, Biehl A, Bika Lele EC, Bikbov M, Bista B, Bjelica DJ, Bjerregaard P, Bjertness E, Bjertness MB, Björkelund C, Blokstra A, Bo S, Bobak M, Boddy LM, Boehm BO, Boeing H, Boggia JG, Boissonnet CP, Bonaccio M, Bongard V, Bopp M, Borchini R, Borghs H, Braeckevelt L, Braeckman L, Bragt MCE, Brajkovich I, Branca F, Breckenkamp J, Breda J, Brenner H, Brewster
LM, Brian GR, Brinduse L, Bruno G, Bueno-de-Mesquita HB, Bugge A, Buoncristiano M, Burazeri G, Burns C, Cabrera de León A, Cacciottolo J, Cai H, Cama T, Cameron C, Camolas J, Can G, Can G, Cândido APC, Cañete F, Capanzana MV, Capuano E, Capuano V, Cardoso VC, Carlsson AC, Carmuega E, Carvalho MJ, Casanueva FF, Casas J-P, Caserta CA, Celikcan E, Censi L, Cesar JA, Chamukuttan S, Chan AW, Chan Q, Chaturvedi HK, Chaturvedi N, Che Abdul Rahim N, Chen C-J, Chen F, Chen H, Chen S, Chen Z, Cheng C-Y, Cheng YJ, Chetrit A, Chikova-Iscener E, Chiolero A, Chiou S-T, Chirlaque MD, Cho B, Cho Y, Christensen K, Christofaro DG, Chudek J, Cifkova R, Cilia M, Cinteza E, Claessens F, Clarke J, Clays E, Concin H, Confortin SC, Cooper C, Coppinger TC, Costanzo S, Cottel D, Cowell C, Craig CL, Crampin AC, Crujeiras AB, Cruz JJ, Cucu A, Cui L, Dallongeville J, Damasceno A, Damsgaard CT, Dankner R, Dantoft TM, D'Arrigo G, Dasgupta P, Dastgiri S, Dauchet L, Davletov K, De Backer G, De Bacquer D, De Curtis A, de Gaetano G, De Henauw S, de Oliveira PD, De Ridder K, de Rooij SR, De Smedt D, Deepa M, Deev AD, Dehghan A, Delisle H, Delpeuch F, Dennison E, Deschamps V, Dhana K, Dhimal M, Di Castelnuovo AF, Dias-da-Costa JS, Diaz A, Dika Z, Djalalinia S, Do HTP, Dobson AJ, Donati MB, Donfrancesco C, Donoso SP, Döring A, Dorobantu M, Dorosty AR, d'Orsi E, Doua K, Drygas W, Duan JL, Duante CA, Duda RB, Duleva V, Dulskiene V, Dumith SC, Dzerve V, Dziankowska-Zaborszczyk E, Eddie R, Egbagbe EE, Eggertsen R, Eiben G, Ekelund U, El Ati J, EldemireShearer D, Eliasen M, Elliott P, Engle-Stone R, Erasmus RT, Erem C, Eriksen L, Eriksson JG, Escobedo-de la Peña J, Evans A, Faeh D, Fall CH, Farrugia Sant'Angelo V, Farzadfar F, Collaboration NCDRF (2019) Rising rural body-mass index is the main driver of the global obesity epidemic in adults. Nature 569:260-264. https://doi. org/10.1038/s41586-019-1171-x

Blaine J, Chonchol M, Levi M (2015) Renal control of calcium, phosphate, and magnesium homeostasis. Clin J Am Soc Nephrol 10:1257-1272. https://doi.org/10.2215 /CJN.09750913

Bohn T, Davidsson L, Walczyk T, Hurrell RF (2004) Phytic acid added to white-wheat bread inhibits fractional apparent magnesium absorption in humans. Am J Clin Nutr 79:418-423. https://doi.org/10.1093/ajen/79.3.418

Cohen L (2000) Physiologic assessment of magnesium status in humans: a combination of load retention and renal excretion. Isr Med Assoc J 2:938-939

Costello RB, Nielsen F (2017) Interpreting magnesium status to enhance clinical care: key indicators. Curr Opin Clin Nutr Metab Care 20:504-511. https://doi.org/10.1097 /MCO.0000000000000410

de Baaij JH, Hoenderop JG, Bindels RJ (2015) Magnesium in man: implications for health and disease. Physiol Rev 95:146. https://doi.org/10.1152/physrev.00012.2014

Del Gobbo LC, Imamura F, Wu JH, de Oliveira Otto MC, Chiuve SE, Mozaffarian D (2013) Circulating and dietary magnesium and risk of cardiovascular disease: a systematic review and meta-analysis of prospective studies. Am J Clin Nutr 98: 160-173. https://doi.org/10.3945/ajcn.112.053132 
EFSA Panel on Dietetic Products Nutrition and Allergies (2015) Scientific opinion on dietary reference values for magnesium. EFSA J 13:4186. https://doi.org/10.2903/j.efsa.2015.4186

Elin RJ (2010) Assessment of magnesium status for diagnosis and therapy. Magnes Res 23:S194-S198. https://doi.org/10.1684 /mrh.2010.0213

Elin RJ (2012) Re-evaluation of the concept of chronic, latent, magnesium deficiency. Magnes Res 24:225-227. https://doi. org/10.1684/mrh.2011.0298

Fang X, Wang K, Han D, He X, Wei J, Zhao L, Imam MU, Ping Z, Li Y, Xu Y (2016) Dietary magnesium intake and the risk of cardiovascular disease, type 2 diabetes, and all-cause mortality: a dose-response meta-analysis of prospective cohort studies. BMC Med 14:210

FAO (2019) The state of food security and nutrition in the world: Safeguarding against economic slowdowns and downturns. Food and Agriculture Organisation of the United Nations (FAO), Rome

Finucane MM, Stevens GA, Cowan MJ, Danaei G, Lin JK, Paciorek CJ, Singh GM, Gutierrez HR, Lu YA, Bahalim AN, Farzadfar F, Riley LM, Ezzati M, C GBMRF (2011) National, regional, and global trends in body-mass index since 1980: systematic analysis of health examination surveys and epidemiological studies with 960 country-years and 9.1 million participants. Lancet 377:557-567. https://doi. org/10.1016/S0140-6736(10)62037-5

Great Britain Panel on Dietary Reference Values (1991) Dietary reference values for food energy and nutrients for the United Kingdom: report of the panel on dietary reference values of the committee on medical aspects of food policy. Department of Health, London

Grober U, Schmidt J, Kisters K (2015) Magnesium in prevention and therapy. Nutrients 7:8199-8226. https://doi.org/10.3390 /nu7095388

Hunt CD, Johnson LK (2006) Magnesium requirements: new estimations for men and women by cross-sectional statistical analyses of metabolic magnesium balance data. Am J Clin Nutr 84:843-852. https://doi.org/10.1093/ajcn/84.4.843

Institute of Medicine (1997) Dietary reference intakes for calcium, phosphorus, magnesium, vitamin D, and fluoride. National Academies Press (US), Washington, DC

Institute of Medicine (2000) Dietary reference intakes: applications in dietary assessment. The National Academies Press, Washington, DC

IRRI (2019) Rice milling and processing [online]. International Rice research institute. Available: http://www. knowledgebank.irri.org/s te p-by-s te p production/postharvest/milling [Accessed 08 March 2019]

Jensen MK, Koh-Banerjee P, Franz M, Sampson L, Gronbaek M, Rimm EB (2006) Whole grains, bran, and germ in relation to homocysteine and markers of glycemic control, lipids, and inflammation 1. Am J Clin Nutr 83:275-283. https://doi. org/10.1093/ajcn/83.2.275

Kass L, Sullivan K (2016) Low dietary magnesium intake and hypertension. World J Cardiovasc Dis 6:447-457. https://doi. org/10.4236/wjcd.2016.612048

Katcher HI, Legro RS, Kunselman AR, Gillies PJ, Demers LM, Bagshaw DM, Kris-Etherton PM (2008) The effects of a whole grain-enriched hypocaloric diet on cardiovascular disease risk factors in men and women with metabolic syndrome. Am J Clin Nutr 87:79-90. https://doi. org/10.1093/ajen/87.1.79

Kristensen M, Toubro S, Jensen MG, Ross AB, Riboldi G, Petronio M, Bugel S, Tetens I, Astrup A (2012) Whole grain compared with refined wheat decreases the percentage of body fat following a 12-week, energy-restricted dietary intervention in postmenopausal women. J Nutr 142:710-716. https://doi.org/10.3945/jn.111.142315

Kumssa DB, Joy EJM, Ander EL, Watts MJ, Young SD, Rosanoff A, White PJ, Walker S, Broadley MR (2015) Global magnesium supply in the food chain. Crop Pasture Sci 66:12781289. https://doi.org/10.1071/Cp15096

Lozano R, Naghavi M, Foreman K, Lim S, Shibuya K, Aboyans V, Abraham J, Adair T, Aggarwal R, Ahn SY, Alvarado M, Anderson HR, Anderson LM, Andrews KG, Atkinson C, Baddour LM, Barker-Collo S, Bartels DH, Bell ML, Benjamin EJ, Bennett D, Bhalla K, Bikbov B, Bin Abdulhak A, Birbeck G, Blyth F, Bolliger I, Boufous S, Bucello C, Burch M, Burney P, Carapetis J, Chen H, Chou D, Chugh SS, Coffeng LE, Colan SD, Colquhoun S, Colson KE, Condon J, Connor MD, Cooper LT, Corriere M, Cortinovis M, de Vaccaro KC, Couser W, Cowie BC, Criqui MH, Cross M, Dabhadkar KC, Dahodwala N, De Leo D, Degenhardt L, Delossantos A, Denenberg J, Des Jarlais DC, Dharmaratne SD, Dorsey ER, Driscoll T, Duber H, Ebel B, Erwin PJ, Espindola P, Ezzati M, Feigin V, Flaxman AD, Forouzanfar MH, Fowkes FG, Franklin R, Fransen M, Freeman MK, Gabriel SE, Gakidou E, Gaspari F, Gillum RF, Gonzalez-Medina D, Halasa YA, Haring D, Harrison JE, Havmoeller R, Hay RJ, Hoen B, Hotez PJ, Hoy D, Jacobsen KH, James SL, Jasrasaria R, Jayaraman S, Johns N, Karthikeyan G, Kassebaum N, Keren A, Khoo JP, Knowlton LM, Kobusingye O, Koranteng A, Krishnamurthi R, Lipnick M, Lipshultz SE, Ohno SL, Mabweijano J, MF MI, Mallinger L, March L, Marks GB, Marks R, Matsumori A, Matzopoulos R, Mayosi BM, JH MA, McDermott MM, McGrath J, Mensah GA, Merriman TR, Michaud C, Miller M, Miller TR, Mock C, Mocumbi AO, Mokdad AA, Moran A, Mulholland K, Nair MN, Naldi L, Narayan KM, Nasseri K, Norman P, O'Donnell M, Omer SB, Ortblad K, Osborne R, Ozgediz D, Pahari B, Pandian JD, Rivero AP, Padilla RP, Perez-Ruiz F, Perico N, Phillips D, Pierce K, Pope CA 3rd, Porrini E, Pourmalek F, Raju M, Ranganathan D, Rehm JT, Rein DB, Remuzzi G, Rivara FP, Roberts T, De Leon FR, Rosenfeld LC, Rushton L, Sacco RL, Salomon JA, Sampson U, Sanman E, Schwebel DC, Segui-Gomez M, Shepard DS, Singh D, Singleton J, Sliwa K, Smith E, Steer A, Taylor JA, Thomas B, Tleyjeh IM, Towbin JA, Truelsen T, Undurraga EA, Venketasubramanian N, Vijayakumar L, Vos T, Wagner GR, Wang M, Wang W, Watt K, Weinstock MA, Weintraub R, Wilkinson JD, Woolf AD, Wulf S, Yeh PH, Yip P, Zabetian A, Zheng ZJ, Lopez AD, Murray CJ, MA AM, Memish ZA (2012) Global and regional mortality from 235 causes of death for 20 age groups in 1990 and 2010: a systematic analysis for the Global Burden of Disease Study 2010. Lancet 380:2095-2128. https://doi.org/10.1016 /S0140-6736(12)61728-0

Lutz W, Sanderson W, Scherbov S (2008) The coming acceleration of global population ageing. Nature 451:716-719. https://doi.org/10.1038/nature06516 
Ma J, Folsom AR, Melnick SL, Eckfeldt JH, Sharrett AR, Nabulsi AA, Hutchinson RG, Metcalf PA (1995) Associations of serum and dietary magnesium with cardiovascular disease, hypertension, diabetes, insulin, and carotid arterial wall thickness: the ARIC study. Atherosclerosis Risk in Communities Study. J Clin Epidemiol 48:927-940. https://doi.org/10.1016 /0895-4356(94)00200-a

Marret S, Marpeau L, Follet-Bouhamed C, Cambonie G, Astruc D, Delaporte B, Bruel H, Guillois B, Pinquier D, ZupanSimunek V, Benichou J, le groupe P (2008) Effect of magnesium sulphate on mortality and neurologic morbidity of the very-preterm newborn (of less than 33 weeks) with two-year neurological outcome: results of the prospective PREMAG trial. Gynecol Obstet Fertil 36:278-288. https://doi. org/10.1016/j.gyobfe.2008.01.012

McCarty MF (2005) Magnesium may mediate the favorable impact of whole grains on insulin sensitivity by acting as a mild calcium antagonist. Med Hypotheses 64:619-627. https://doi.org/10.1016/j.mehy.2003.10.034

NCD-RisC (2016) Trends in adult body-mass index in 200 countries from 1975 to 2014: a pooled analysis of 1698 population-based measurement studies with $19 \cdot 2$ million participants. Lancet 387:1377-1396. https://doi.org/10.1016 /s0140-6736(16)30054-x

Nielsen FH (2015) Importance of plant sources of magnesium for human health. Crop Pasture Sci 66:1259-1264. https://doi. org/10.1071/Cp15072

Nielsen FH (2019) The problematic use of dietary reference intakes to assess magnesium status and clinical importance. Biol Trace Elem Res 188:52-59. https://doi.org/10.1007 /s12011-018-1573-x

Nielsen FH, Johnson LA (2017) Data from controlled metabolic ward studies provide guidance for the determination of status indicators and dietary requirements for magnesium. Biol Trace Elem Res 177:43-52. https://doi.org/10.1007/s12011016-0873-2

Razzaque M (2018) Magnesium: are we consuming enough? Nutrients 10:1863. https://doi.org/10.3390/nu10121863

Romani AM (2011) Cellular magnesium homeostasis. Arch Biochem Biophys 512:1-23. https://doi.org/10.1016/j. abb.2011.05.010

Romani AM, Scarpa A (2000) Regulation of cellular magnesium. Front Biosci 5:D720-D734. https://doi.org/10.2741/Romani

Rosanoff A (2013) Changing crop magnesium concentrations: impact on human health. Plant Soil 368:139-153. https://doi.org/10.1007/s11104-012-1471-5

Rosanoff A, Weaver CM, Rude RK (2012) Suboptimal magnesium status in the United States: are the health consequences underestimated? Nutr Rev 70:153-164. https://doi. org/10.1111/j.1753-4887.2011.00465.x

Rosique-Esteban N, Guasch-Ferre M, Hernandez-Alonso P, SalasSalvado J (2018) Dietary magnesium and cardiovascular disease: a review with emphasis in epidemiological studies. Nutrients 10:168. https://doi.org/10.3390/nu10020168

Rubin H (2005) Membrane stabilization by intimate contact between cells reduces their $\mathrm{Mg} 2+$ activity and suppresses the neoplastic phenotype. Semin Cancer Biol 15:121-131. https://doi.org/10.1016/j.semcancer.2004.08.003

Seeling MS (1964) The requirement of magnesium by the normal adult summary and analysis of published data. Am J Clin Nutr 14:342-390. https://doi.org/10.1093/ajcn/14.6.342

Seeling MS, Rosanoff A (2003) The magnesium factor. Avery Penguin Group, New York

Takaya J, Yamato F, Kaneko K (2006) Possible relationship between low birth weight and magnesium status: from the standpoint of "fetal origin" hypothesis. Magnes Res 19:6369

Tsang RC, Oh W (1970) Serum magnesium levels in low birth weight infants. Am J Dis Child 120:44-48. https://doi. org/10.1001/archpedi.1970.02100060078010

Verma H, Garg R (2017) Effect of magnesium supplementation on type 2 diabetes associated cardiovascular risk factors: a systematic review and meta-analysis. J Hum Nutr Diet 30:621633. https://doi.org/10.1111/jhn.12454

Volpe SL (2012) Magnesium. In: Erdman JW Jr, MacDonald IA, Zeisel SH (eds) Present knowledge in nutrition, 10th edn. John Wiley \& Sons, Iowa, USA

Wallach S (1988) Availability of body magnesium during magnesium deficiency. Magnesium 7:262-270

WHO (2019a) Growth reference data for 5-19 years [online]. World Health Organisation (WHO) Available: https://www. who.int/growthref/en/ [Accessed February 15 2019]

WHO (2019b) Weight-for-age boys chart: Birth to 5 years (zscores) [online]. World Health Organisation (WHO). Available: https://www.who.int/childgrowth/standards/cht wfa_boys_z_0_5.pdf?ua=1 [Accessed February 15 2019]

WHO (2019c) Weight-for-age girls: Birth to 5 years (z-scores) [online]. World Health Organisation. Available: https://www. who.int/childgrowth/standards/cht_wfa_girls_z_0_5. pdf?ua=1 [Accessed February 19 2019]

WHO, FAO (2003) Diet, nutrition and the prevention of chronic diseases: report of a joint WHO/FAO expert consultation, Geneva, 28 January-1 February 2002. World Health Organization, WHO Technical Report Series

WHO, FAO (2004) Vitamin and mineral requirements in human nutrition. World Health Organization (WHO) and Food and Agriculture Organization of the United Nations (FAO), Geneva

Zhang W, Iso H, Ohira T, Date C, Tamakoshi A, Group JS (2012) Associations of dietary magnesium intake with mortality from cardiovascular disease: the JACC study. Atherosclerosis 221:587-595. https://doi.org/10.1016/j. atherosclerosis.2012.01.034

Zhang X, Li Y, Del Gobbo LC, Rosanoff A, Wang J, Zhang W, Song Y (2016) Effects of magnesium supplementation on blood pressure: a meta-analysis of randomized double-blind placebo-controlled trials. Hypertension 68:324-333. https://doi.org/10.1161/hypertensionaha.116.07664

Publisher's note Springer Nature remains neutral with regard to jurisdictional claims in published maps and institutional affiliations. 